Discussion Paper No. 11-085

\title{
How Does the Domiciliation Decision Affect Mutual Fund Fees?
}

Gunnar Lang and Matthias Köhler

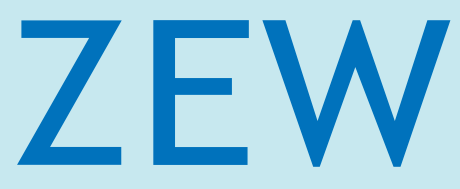

Zentrum für Europäische Wirtschaftsforschung $\mathrm{GmbH}$ Centre for European Economic Research 
Discussion Paper No. 11-085

\title{
How Does the Domiciliation Decision Affect Mutual Fund Fees?
}

\author{
Gunnar Lang and Matthias Köhler
}

Download this ZEW Discussion Paper from our ftp server:

http://ftp.zew.de/pub/zew-docs/dp/dp11085.pdf

Die Discussion Papers dienen einer möglichst schnellen Verbreitung von neueren Forschungsarbeiten des ZEW. Die Beiträge liegen in alleiniger Verantwortung der Autoren und stellen nicht notwendigerweise die Meinung des ZEW dar.

Discussion Papers are intended to make results of ZEW research promptly available to other economists in order to encourage discussion and suggestions for revisions. The authors are solely responsible for the contents which do not necessarily represent the opinion of the ZEW. 


\section{Non-technical summary}

In this paper, we analyze if the integration of the European mutual funds industry has brought advantages to private and institutional investors. Moreover, we examine the possible determinants of fund fees as well as the effects of domiciliation decisions of fund companies. Investors worldwide invest in more than 65,000 different investment funds, since these are perceived to be liquid and diversified assets with lower cost than direct investments. The fees investors are generally charged include fees for the fund's set-up, portfolio management, custody of the shares, marketing and sales etc. In theory, higher fees result in a lower investment performance. Yet it has been shown that there exists no correlation between higher fund fees and good fund performance. For the fund company, however, higher fees translate directly into higher profits, i.e. there is a conflict of interest between the market participants. As a result of legal and regulatory harmonization in the European financial industry, competition between fund companies has risen greatly over the past few years. In order to benefit from economies of scale, fund companies have concentrated their activities in a single location. This has also led to increased competition between countries seeking to attract these financial institutions. In this respect, Luxembourg and Ireland play a particular global role as specialized financial centers. However, the question arises whether investors really benefit from this market concentration beyond the greater number of investment opportunities.

The results show that the fees charged by funds differ significantly across countries and across fund types. It is also shown that funds domiciled in Luxembourg have considerably lower cross-border distribution costs. This advantage is, however, countered by several drawbacks. Generally, funds complying with UCITS policy are most expensive for investors. Furthermore, fees rise with an increase in the number of countries in which the fund is distributed, as additional distribution partners and permits are required. The results do not clearly show that investors pay lower fees for funds from Luxembourg or Ireland than for funds of other countries. All in all, it is shown that the market integration of the European fund industry has reduced costs significantly, due mainly to the concentration of specialists in clusters and economies of scale, leading to greater welfare. The implementation of the UCITS IV Directive has increased the need for a more thorough examination of the supply side of the fund industry. 


\section{Das Wichtigste in Kürze}

Diese Arbeit geht der Frage nach, ob die europäische Finanzmarktintegration im Bereich der Fondsindustrie zu Vorteilen für Privatanleger und institutionelle Investoren geführt hat. Dabei werden mögliche Determinanten der Fondsgebühren und die Auswirkungen der Domizilierungsentscheidung der Fondsgesellschaft untersucht. Investoren investieren weltweit in mehr als 65.000 verschiedene Investmentfonds, um so, im Vergleich zu Direktinvestments, in liquide und diversifizierte Anlagen $\mathrm{zu}$ relativ geringen Kosten anzulegen. Investoren müssen generell eine Fondsgebühr bezahlen, die als Preis unter anderem für die Fondsauflage, Portfoliomanagement, Wertpapieraufbewahrung und den Vertrieb erhoben wird. Höhere Gebühren bedeuten für den Investor grundsätzlich eine geringere Investitionsrendite. Es zeigt sich zudem, dass keine Beziehung zwischen hohen Fondsgebühren und guter Fondsperformance besteht. Allerdings führen höhere Fondsgebühren gleichzeitig zu höheren Gewinnen auf Seiten der Fondsgesellschaft, so dass sich ein Spannungsfeld zwischen den Marktakteuren ergibt. Begünstigt durch rechtliche Harmonisierungen in der europäischen Finanzindustrie hat sich der Wettbewerb zwischen den Fondsgesellschaften in den letzten Jahren weiter erhöht. Um von Skaleneffekten zu profitieren, konzentrieren Fondsgesellschaften ihre Tätigkeiten an einzelnen Standorten, was auch zu einem erhöhten Wettbewerb zwischen Ländern um die höchste Standortattraktivität führt. Luxemburg und Irland spielen als spezialisierte Finanzzentren global eine besondere Rolle. Jedoch stellt sich die Frage, inwieweit Investoren von dieser Marktkonzentration profitieren, außer dass sich die Anzahl ihrer Anlagemöglichkeiten erhöht?

Die Ergebnisse zeigen, dass erhebliche Unterschiede in der Höhe der Fondsgebühren zwischen Ländern und Fondstypen bestehen. Ebenso zeigt sich, dass deutlich geringere Kosten für den grenzüberschreitenden Vertrieb der in Luxemburg ansässigen Fonds anfallen. Diesen Vorteilen stehen aber ebenso Nachteile gegenüber. Fonds die die OGAW-Richtlinie erfüllen, sind für den Investor grundsätzlich teurer. Zusätzlich erhöht sich die Fondsgebühr mit der Anzahl an bestehenden Vertriebsländern, da zusätzliche Vertriebspartner und Genehmigungen benötigt werden. Die Resultate zeigen aber nicht wirklich, dass Investoren niedrigere Gebühren für Fonds aus Luxemburg und Irland im Vergleich zu Fonds aus den anderen Ländern zahlen müssen. Insgesamt wird aber festgestellt, dass die Marktintegration in der europäischen Fondsindustrie signifikante Kostensenkungen durch die Konzentration von Spezialisten im Cluster und Skaleneffekte bewirkt und somit $\mathrm{zu}$ Wohlfahrtsverbesserungen führt. Die Umsetzung der aktuellen OGAW IV-Richtlinie in der EU verstärkt die Notwendigkeit, die Angebotsseite der Fondsbranche genauer zu untersuchen. 


\title{
How Does the Domiciliation Decision Affect Mutual Fund Fees? ${ }^{1}$
}

\author{
Gunnar Lang \\ Centre for European Economic Research (ZEW), Mannheim \\ Matthias Köhler \\ Deutsche Bundesbank, Frankfurt/Main
}

This version: December 2011

\begin{abstract}
In this paper, we analyze whether the domiciliation decision of mutual funds has an impact on fund fees. To explain the fee price-setting of mutual funds, we consider characteristics specific to funds, fund companies, and countries. We find that fees vary considerably across fund types and countries. Positive impacts of financial market integration can be confirmed, though funds set up under the UCITS directive are more expensive. If funds are sold in multiple countries it drives up fees; however, these higher costs for the investor are outweighed by economies of scale that can be generated if the domiciliation is in a specialized financial center, such as Luxembourg. Larger funds and funds that are set up by specialized or larger fund companies have significantly lower fees.
\end{abstract}

Keywords: Mutual Funds, Financial Regulation, Market Integration

JEL-Classification: F36, G15, G18, G20, L11

\footnotetext{
1 Corresponding author: Gunnar Lang, Centre for European Economic Research (ZEW), Department of International Finance and Financial Management, P.O. Box 1034 43, 68161 Mannheim, Germany, Phone +49 6211235 372, Email lang@zew.de

Acknowledgements: We are grateful to Waldemar Rotfuß, Henry Schäfer, Michael Schröder, Ed Szymanoski, Peter Tufano and Tereza Tykvova for discussions as well as participants in the various seminars where this work was presented. The paper was partially written while Gunnar Lang was Visiting Researcher in the Finance Unit of Harvard Business School whose hospitality he greatly appreciated. All errors are our own.
} 


\section{Introduction}

In late 2006, shortly before the financial crisis, more than 65,000 different mutual funds were sold around the globe with the aim of offering investors more liquid and diversified investments at relatively low costs in comparison to direct investments in individual assets. For investors, fund fees comprise the price for management, set-up, custodian, distribution and other services related to these funds. On the one hand, it can be argued that higher fees adversely affect investment performance. However, several studies give evidence that the variation in fund performance is not explained by fees; high-cost funds may underperform low-cost funds (Malkiel, 1995; Gruber, 1996; Carhart, 1997; Otten and Bams, 2002 and 2011), but this can rather be explained by fund managers characteristics with superior assetpicking and fund management skills (e.g. Chevalier and Ellison, 1999 or Cohen, 2008). On the other hand, higher fees can increase the profitability of the issuing fund company. However, fund companies risk losing market share when they charge higher fees than their competitors (Khorana and Servaes, 2007). Funds face competition in both national and supranational markets. In national markets, funds are sold only to investors in the country in which the fund is domiciled. By contrast, supranational funds are sold across borders. The cross-border distribution of funds has increased worldwide over the past decades owing to a reduction of barriers to the cross-border sale of funds. This has intensified competition among fund companies and has provided incentives to relocate their activities and to domicile their funds in countries which offer the most favorable regulatory environment. This, in turn, has led to greater competition among countries seeking to attract fund companies.

In the EU, competition among countries for the best regulatory framework is intensified by the directive on Undertakings for Collective Investments in Transferable Securities (UCITS), which has created a standardized pan-European market through the introduction of a "product passport" for mutual funds. This passport allows any fund registered in one EU country to be sold in any other EU country without further lengthy authorization proceedings. 
This standardization also applies to fund companies from outside the EU searching for the one domicile in Europe from which to offer funds to the entire continent. EFAMA (2010) reports that the majority of funds domiciled in the EU are in compliance with UCITS, accounting for 79 percent of the value and 72 percent of the number of all EU funds in 2006. Owing to a favorable regulatory environment and tax system, Luxembourg and Ireland have particularly benefited from the introduction of the UCITS directive and have evolved into financial centers used by fund companies to distribute their funds around the globe. The concentration of funds domiciled in financial centers is further reinforced by cluster effects from agglomeration and economies of scale. Economic theory predicts that these cluster effects should lead to lower prices, better product quality, more rapid technological improvements and, thus, greater consumer welfare.

Our results show that the introduction of the UCITS directive has created a European market for mutual funds by facilitating the cross-border distribution of funds. However, owing to greater administrative requirements, UCITS funds are more costly to set up than non-UCITS funds. Furthermore, funds sold in many countries are often more expensive than funds sold in a smaller number of countries. These disadvantages may be outweighed by the significant economies of scale that can be generated if the domiciliation of funds is centralized in financial centers. Moreover, financial integration creates economic benefits by encouraging the concentration of fund specialists in such clusters. These benefits are reflected by significantly lower costs for the cross-border distribution of Luxembourg-based funds compared to funds domiciled in other countries. Our results are based on a dataset on mutual fund fees charged by more than 12,000 mutual funds around the world between 1997 and 2006, covering 80 and 75 percent, respectively, of total global fund starts based on fund size and the total number of funds launched.

Our paper complements the literature on mutual fund fees in several aspects. Some studies suggest that economies of scale and scope exist for larger fund companies, which may 
be reflected in lower fund fees or enhanced net performance. These studies mainly analyze US equity and fixed income funds (e.g. Collins and Mack, 1997; Latzko, 1999; Ang and Lin, 2001 and Chen et al., 2004). Elton et al. (2003) show that performance-based fees increase market demand, while Barber et al. (2005) and Wilcox (2003) find that investors are more reluctant to accept non-recurring fees, such as front-loads, than recurring expenses. ${ }^{2}$ Ruenzi (2006) examines the fee structures for different fund classes of one fund. He finds that front loads alone do not lead to a separation of investors, but that a combination of recurring and non-recurring fees usually lead to the best outcome for investors. More recently, Gil-Bazo and Ruiz-Verdu (2009) show that funds with inferior before-fee performance levy higher fees. The authors seize on the findings of Christoffersen and Musto (2002) and explain the relation between fees and performance as the result of different strategic fee-settings by the fund company in the presence of investors with different degrees of sensitivity to fund performance.

The study most closely related to our paper is Khorana et al. (2009). They focus on the determinants of mutual fund fees and show that there is substantial variation in fees worldwide. Fees vary by investment objective and fund type. In addition, they find that larger funds and larger fund companies charge lower fees, while funds distributed in a greater number of countries charge higher fees, as do funds domiciled in so-called "offshore locations" such as Ireland and Luxembourg. ${ }^{3}$ This is consistent with our dataset which shows

\footnotetext{
${ }^{2}$ In earlier papers, Chordia (1996) and Nanda et al. (2000) analyze the optimal price setting of funds. Chordia (1996) assumes that the fund market is a monopoly in order to analyze the price setting behavior of fund companies offering two different funds, while Nanda et al. (2000) presume that fees are determined endogenously in a competitive fund market.

${ }^{3}$ Khorana et al. (2005) and, in a similar approach, Fernando et al. (2003) with a focus on mutual fund industry growth, investigate why in some countries funds have been widely adopted in investors' portfolios and less so in others. Hence, their analyses focus especially on demand-side factors. Khorana et al. (2005) find that the demand for mutual funds is higher in countries with stricter rules, laws, and regulations, specifically where mutual fund investors' rights are better protected. The fund industry is also found to be larger in countries with a wealthier and more educated population and with an older fund industry. Fernando et al. (2003) find that better developed market-based financial systems, as well as higher market returns, liquidity and lower volatility have a positive influence on market growth. In high-income countries, openness to trade and a higher share of high-tech exports is conducive, while in middle-income countries per capita income and strong banking systems contribute to market growth. Furthermore, the legal origin is important (equity funds are more advanced in common law
} 
that funds domiciled in Luxembourg are significantly more expensive than funds domiciled in other countries despite the benefits often attributed to financial clusters: agglomeration effects, backward and forward linkages in the value-added chain, and increasing economies of scale (Krugman, 1991 and Venables, 1996). In the fund industry, for example, having many fund administration specialists may lead to lower costs for all firms in the cluster, since they can share common services and knowledge or hire specialists without having to pay relocation costs.

This may be important for fund companies, as indicated by a recent survey by Lang (2012) among executives of predominantly German fund companies. The survey suggests that the decision on where to domicile a fund is not primarily driven by cost factors such as registration charges, fund company tax burden and labor costs, but rather by the quality of the workforce and the approval process which may allow firms to set up more innovative and complex funds in a shorter period of time than in other countries. Thus traditional cost factors do not seem to be the primary reason to domicile a fund in financial centers. This may explain why funds from Luxembourg continue to charge higher fees than funds from other countries.

Higher fees in financial centers may also be due to path dependence and lock-in effects (Krugman, 1991; Martin and Sunley, 2006; Sydow et al., 2009). ${ }^{4}$ For the mutual fund industry, this may imply that funds are domiciled in Luxembourg because the structures necessary to set up such funds already exist in this country and not because of a favorable environment for the mutual fund industry. Hence, higher fees may also be the result of inefficient existing market structures. Another reason for the high level of fees may be that funds from Luxembourg are often designed for sale in other countries. The rising number of distributors in different countries may increase costs for the fund company, as more negotiations are required on sales conditions and margins for the involved parties.

countries and fixed income funds are more advanced in civil law systems) and restrictions on competing products enhance market development.

${ }^{4}$ Porteous (1999) applies the concept of historical path dependence to financial centers, which may leads to a lock-in-effect. 
Furthermore, registering funds in several markets significantly raises costs, which may outweigh the potential benefits arising from agglomeration effects and scale economies. If supranational funds from Luxembourg comply with the UCITS Directive and avoid the crossborder distribution costs of registering in multiple markets, the added administrative burdens may increase the overall costs of UCITS funds compared to non-UCITS funds.

Our results indicate that the distribution of funds across borders indeed significantly increases fees. Our estimates suggest that selling a fund in seven countries instead of only one country increases the total expense ratio by almost 30 basis points. Complying with the UCITS directive raises mutual fund fees by an additional seven basis points. However, we also find that distributing funds from Luxembourg abroad is significantly less costly than from other countries in our sample. To illustrate, our results suggest that a fund domiciled in Luxembourg and sold in seven countries has a total expense ratio which is 24 basis points lower than that of a fund domiciled in another country and sold in the same number of countries. This indicates that Luxembourg offers significant cost advantages in the crossborder distribution of funds.

Our results further show that the size of the fund and the size of the originating mutual fund company affect mutual fund fees by reducing administration and management costs through economies of scale. These cost benefits are passed through to investors. More specialized fund companies charge lower fees, indicating efficiency gains from experience effects and specialist knowledge. Furthermore, fund companies charge higher fees if they are domiciled in countries that legally require an independent custodian. The time necessary to start a mutual fund and to fulfill all regulatory requirements matters as well. However, in contrast to the intuition that a longer start-up period increases fees, we find the opposite. Funds issued with shorter start-up time may have competitive advantages relative to funds that have longer start-up times. This may be particularly relevant for funds investing in asset classes that are subject to current market trends, such as gold or other commodities, and may 
give fund companies greater scope to raise fees due to less cost-sensitive investors, such as those seeking for huge returns. This may also explain why funds in Luxembourg continue to charge higher fees than funds domiciled in most other countries despite the favorable regulatory environment and scale economies that can be generated by domiciling funds in financial centers.

The remainder of this paper is structured as follows: Section 2 describes the data and provides extensive descriptive statistics on possible determinants of mutual fund fees, while the econometric model and our results are compiled in Section 3. In Section 4, we check whether our results are driven by the choice of the sample and test whether Luxembourg and Ireland have competitive advantages in distributing mutual funds abroad. Section 5 summarizes our findings.

\section{Data and Mutual Fund Fees}

\subsection{Dataset}

The sample is based on data on mutual funds (open-end pooled investment vehicles that invest in transferable securities and are traded at the fund's net asset value) that were set up around the world between 1997 and 2006. A relatively new sample period is needed to account for the market integrating effects resulting from the recent facilitation of cross-border sales and domiciliation in different jurisdictions. The domicile is the country in which a fund is legally registered. The year 2006 was chosen as a cut-off point to prevent distortions caused by the financial crisis. Our sample covers 80 percent of the total mutual fund starts based on fund size and 75 percent based on the number of funds started. The information on mutual fund starts comes from Morningstar Direct. ${ }^{5}$ We use the inception date in Morningstar for

\footnotetext{
${ }^{5}$ Furthermore, we focus on worldwide cross-border transactions. For this reason, we cannot use the US survivorship free database CRSP. Morningstar Direct attempts to distinguish between all investments and only surviving investments but understates the reality of closed funds. The CRSP database lists every single share class of a fund as an individual entry. Our sample is not free of survivorship bias. If the disappeared group of 
matching, i.e. the date on which the fund began operating. Any fund not characterized as the oldest share class is excluded to account for errors caused by duplicity of observations in our data. ${ }^{6}$ Furthermore, we drop all observations for which we do not have information on fees and fund size.

Table 1 indicates that annual mutual fund starts increased between 1997 and 2006. Fernando et al. (2003) and Heinemann (2002) relate the growth of mutual funds during the 1990s to the globalization of financial markets, a strong performance of equity and bond markets, an increased demand for mutual funds by an aging population in high- and middle income countries, as well as to the search for safe, liquid but high-return investments. The rise in the number of mutual fund funds starts was interrupted by the stock market crash in 2002 and 2003, which led to a significant reduction of mutual fund starts which is reflected by our sample.

[insert Table 1 about here]

The distribution of funds broken down by fund type is shown in Table 2. Our sample includes allocation $(2,138)$, alternative $(1,575)$, equity $(5,497)$, fixed income $(1,960)$ and money market funds (565). ${ }^{7}$ Allocation funds mix equity, bonds, and cash, while alternative funds invest in currencies, derivatives as well as commodities and may employ shorting as a strategy. In contrast to allocation and alternative funds with possible specific derivative structures, equity and fixed income funds more easily qualify for a UCITS passport. This is reflected in Table 2, which shows that more than 50 percent of equity and fixed income funds in our sample are UCITS funds. In Luxembourg and Ireland, even 90 percent of all funds are compliant with the UCITS directive.

closed funds did not depend on observable characteristics of the funds, we would not have a bias, but studies show e.g. closed funds to be smaller than surviving funds (Carhart, 1997; Zhao, 2005).

${ }^{6}$ Sometimes, the same fund is recognized twice or more times in the Morningstar database, for example, emitted in different currencies. Given that the content of these funds is the same with different share classes, additional observations for one domiciliation could bias our results and will be omitted. Similarly, Morningstar often publishes the same fund assets for different share classes.

${ }^{7}$ Municipal fixed income funds are excluded as they are mostly driven by US tax reasons. 
[insert Table 2 about here]

Table 3 provides an overview of the geographical distribution of mutual funds and their origins. The total sample comprises 11,735 mutual funds from 22 countries. The countries in which most funds are domiciled are Luxembourg $(2,934)$ and the United States $(1,984)$. We distinguish between funds domiciled by fund companies with a foreign parent company and funds started by a domestic fund company. In Luxembourg, funds domiciled by foreign fund companies are much more important than in all other countries. Both countries combined account for more than two thirds of all funds started by foreign fund companies worldwide.

[insert Table 3 about here]

These fund companies primarily use Luxembourg and Ireland as hubs to distribute their funds abroad, as indicated in Table 4. Funds from Luxembourg are, on average, distributed in almost 12 countries, while funds domiciled in Ireland are, on average, sold in almost 9 countries. Although these funds are also registered for sale in Luxembourg and Ireland, they are mainly sold abroad. In contrast, in most other countries in our sample mutual funds are mainly sold in a single market - the country in which they are domiciled - and not set up for cross-border distribution.

[insert Table 4 about here]

The large number of foreign fund companies and the large number of countries in which funds are sold reflect Luxembourg and Ireland's role as financial centers for the mutual fund industry. Both countries have developed into financial centers owing to the fast implementation of the UCITS directive and the creation of a favorable environment for the European mutual fund industry. In 1988, Luxembourg became the first EU Member State to transpose the directive concerning UCITS into national law. The legal and regulatory environment thus created a competitive edge for Luxembourg as a first mover over rival 
financial centers. Ireland was popular for low corporate tax rates and other incentives for companies to set up operations in Dublin's International Financial Services Centre established in 1987. The Irish mutual fund industry evolved in 1989, when the UCITS directive was implemented in Ireland, providing a competitive advantage for mutual funds set up in Ireland owing to a combination of low tax rates for fund companies and easy access to the EU market via the product passport. In the following years, Ireland enacted several legal changes ensuring full availability of fund products managed by international fund companies. This regulatory flexibility combined with the enactment of a tax exemption for Irish domiciled funds in 2000 and the sales permission of the funds to domestic investors has resulted in an enormous growth of the mutual fund industry in Ireland. Both locations are not just used for sales in the EU, they have established themselves as locations to domicile mutual funds to be sold worldwide.

\subsection{Fragmentation of Mutual Fund Fees}

The aim of this paper is to analyze the determinants of mutual fund fees. In general, fees can be divided into performance-based fees and non-performance-based fees. Performance-based fees are charged when performance exceeds certain pre-specified benchmarks. Since they play a minor role in the global mutual fund industry, except in the segment of hedge funds, and are not related to domiciliation costs, we concentrate on non-performance-based fees. ${ }^{8}$ The latter can further be categorized into non-recurring fees that are charged once and those that are charged frequently. Fees charged once can be front loads, redemption fees, or conditioned redemption fees. In most cases, funds charge a combination of one-off and

\footnotetext{
${ }^{8}$ Performance-based fees are not common in the US because mutual fund fees have had to be symmetric since 1970 (Khorana and Servaes, 2008). Elton et al. (2003) study performance-based fees in the US and find that in 1999 only 1.7 percent of all funds charged incentive fees, but these funds control 10.5 percent of all fund assets. On average these funds do not earn any performance-based fees, because they do not outperform their benchmarks. Sigurdsson (2007) finds that in Europe especially equity funds with a share in assets of 12 percent have incentive elements.
} 
recurring fees. ${ }^{9}$ It cannot be determined exactly how much the investor is charged through non-recurring price elements, because most of the distribution channels usually give investors various discounts. Therefore, the actual fees paid may differ from the fees published because of the bargaining power of institutional investors. The published non-recurring fees in our dataset are thus the maximum rates and may be negotiated to lower levels. ${ }^{10}$ Front loads are usually levied for distribution. Hence, they are income for the distributor rather than for the fund company. The discounts increased between 1997 and 2006, resulting in larger differences for old funds. The difference between the posted and paid fee also varies between countries. Fees are maintained over time once they are established. Fund companies cannot select the countries and apply different non-recurring fees in the main share class. Including front and end load fees would have a distorting effect as frequent transactions, i.e. buying and selling funds are not representative. The typical buy-and-hold investor tends to invest based on long-term considerations. For this reason, we concentrate on recurring fees.

We follow the literature (e.g. Khorana et al., 2009 and Bergstresser et al., 2009) and use the following two measures of recurring mutual fund fees: (1) total expense ratio (TER) and (2) management fee (MGFEE). Data on mutual fund fees comes from Morningstar Direct, which gathers the data from the funds' annual reports. Management fees are the annual revenues of the investment management. They are used to pay investment advisers for supervising and rebalancing a fund's portfolio as well as for managing its operations. ${ }^{11}$ The total expense ratio includes not only management fees, but all annual expenses levied by a

\footnotetext{
${ }^{9}$ The share of the recurring part in the total revenues of a US or European mutual fund company has been increasing for years (Ruenzi, 2006). This result may stem from the large increase in fund volume and the fact that the number of no-load funds has increased over the past years. Barber et al. (2005) show that investors treat different types of fees differently and pay more attention to fees that are more apparent, such as front-loads, and not the annual expenses.

${ }^{10}$ To index these one-time costs Khorana et al. (2009) assume an investor's average holding period of five years and split the front and back-end loads.

${ }^{11}$ Portfolio managers in the fund management are located independently from legal domiciliation and frequently work in teams. According to the findings of Bär et al. (2011), fund companies prefer a portfolio management in a team of managers when funds are on average larger and specialized knowledge is essential and therefor cite balanced funds as an example. In some cases, fund companies employ another company, called the sub-advisor, to handle the fund's day-to-day management, e.g. due to specific industry knowledge. In these instances, the portfolio manager is generally located in the same place as the fund's sub-advisor.
} 
fund on its investors, covering distribution, administration, custodian, transfer agent, accounting, audit, legal and others. It, hence, is a much broader definition of mutual fund fees than management fees. ${ }^{12}$ In addition, we extend the two measures by a compound ratio calculating the difference between the total expense ratio and management fee as a proxy for (3) administrative fees (ADFEE). Administrative fees should better reflect domiciliation costs, because the fund management is usually located in a country other than the fund domicile. ADFEE should measure costs unrelated to the fund management such as fees for the custodian, transfer agent, accounting, audit, legal companies and for own administrative functions of a fund company. ${ }^{13}$

Table 5 provides an overview of the fees of these three measures of recurring fees by country of domiciliation. We compare the asset-weighted and unweighted average levels of fees for all funds as well as for allocation, alternative, equity, fixed income and money market funds. We feel that asset-weighted fees are a better representation of the fees paid by the consumer. Mutual fund fees vary considerably from country to country. For example, on an asset-weighted basis, mean total expense ratios range from 0.59 in Switzerland to 1.92 in Finland. Funds from Luxembourg have a mean expense ratio of 1.45 (weighted by fund size). This does not place it among the most affordable funds despite the cluster effects attributed to financial clusters. Irish funds, in contrast, have a much lower mean expense ratio of 1.05 (weighted by fund size). Similar results are obtained for management and administrative fees. Although this perspective neglects the influence of other important variables, such as fund

\footnotetext{
${ }^{12}$ Morningstar publishes several expense ratios with different levels of coverage. We use the audited trailing perspective of the annual report net expense ratio, which is the "percentage of fund assets used to pay for operating expenses and management fees, including $12 \mathrm{~b}-1$ fees, administrative fees, and all other asset-based costs incurred by the fund. Fund expenses are reflected in the fund's NAV. According to the analyses of Khorana et al. (2009), it typically includes "the following types of fees: accounting, administrator, advisor, auditor, board of directors, custodial, distribution (12b-1), legal, organizational, professional, registration, shareholder reporting, sub-advisor, and transfer agency." It does not reflect the fund's brokerage costs. Sales charges are also not included in the expense ratio, because "the charge may vary depending on the amount invested and the fund chosen", ICI (2010: 190-191).

${ }^{13}$ However, since published management fees usually differ in terms of the services included, ADFEE may also include costs unrelated to the set-up and running of funds. Despite these limitations we think that the addition of ADFEE gives us a more representative picture of the fee structure as it serves as a proxy for the local differences in efficiency rather than salary levels.
} 
type and the number of countries in which a fund is sold, it is striking that Luxembourg continues to charge higher fees than most other countries despite the cost advantages that may arise from industry size advantages and cluster effects, which are usually attributed to financial centers.

[insert Table 5 about here]

\subsection{Determinants of Mutual Fund Fees}

In the following, we present descriptive statistics of mutual fund fees in order to identify potential determinants that may explain why fees differ across countries. An important determinant of mutual fund fees is the fund type, since factors such as different creative leeway in the regulation of the fund and the fund company or different authorization proceedings for underlying assets and the use of hedging instruments with derivatives should be more relevant for some fund types than for others. This is reflected in Table 6, which shows that equity ${ }^{14}$ and allocation funds are, on average, the most expensive, while money market and fixed income funds are the cheapest, owing to lower transaction and management costs. Furthermore, competition from banks and insurance companies is greater for the latter two types of funds, because deposit products are a direct competitor to fixed income and money market funds. ${ }^{15}$ This should reduce the scope of fund companies to raise fees on money market and fixed income funds.

[insert Table 6 about here]

Another important determinant of mutual fund fees may be the number of countries in which a mutual fund is sold. Since mutual fund companies have to incur registration costs for each country in which the fund is sold, fees should rise as the number of countries in which a

\footnotetext{
${ }^{14}$ Cooper et al. (2011) analyze dispersion in mutual fund fees and find evidence of systematic differences in prices across US equity funds.

${ }^{15}$ The variation in management fees is rarely a result of the ratio of the non-recurring to the recurring part of the total fees (e.g. Spanish funds have traditionally been sold without a load fee, a fact that explains some of the highest management fees in Europe).
} 
fund is sold increases. This is reflected in Table 7, which shows a positive relationship between mutual fund fees and the number of countries in which a fund is sold. To illustrate, selling a fund in over seven countries should raise the asset-weighted total expense ratio, on average, by almost 60 basis points compared to a fund which is sold in only one country. This may explain why funds domiciled in Luxemburg report higher fees than funds domiciled in other European countries, although the UCITS regulation should lead to similar fees across the EU (European Commission, 2009).

[insert Table 7 about here]

Fund size is an important determinant of mutual fund fees as well. Larger funds should generate economies of scale in fund management and administration, leading to lower mutual fund fees. ${ }^{16}$ This is illustrated in Table 8 , which relates mutual fund fees to fund size. Table 8 indicates that average mutual fund fees decrease as the size of the fund increases. For example, a fund that belongs to the first quartile based on fund size has an average total expense ratio of 1.57 weighted by assets. In contrast, a fund in the fourth quartile has a significantly lower average total expense ratio of 1.02 . The negative relationship is also observable for management and administrative fees, although fees tend to increase at lower fund sizes, before they start to decrease. This may indicate that fund companies have to incur fixed overhead costs for fund management and administration in the first stage, before economies of scale lead to lower average costs. To control for the non-linear relationship between fund size and fees, we later include a squared term in the regression analysis. In addition, we test whether economies of scale also derive from a greater size of the mutual fund company.

[insert Table 8 about here]

\footnotetext{
${ }^{16}$ Earlier studies indicate economies of scale in the mutual fund industry for the US (Baumol et al., 1980 and France (Dermine and Röller, 1992).
} 


\section{Econometric Model}

Since the determinants of mutual fund fees are correlated, we estimate the following regression model to isolate the effect of several fund-, company- and country-specific variables on mutual fund fees:

$F_{e e} e_{\mathrm{ijct}}=\alpha+\beta_{1} F U N D T Y P E_{i}+\beta_{2} X_{i j c t}+\beta_{3} Z_{i j c t}+\beta_{4} Y_{c t}+\varepsilon_{i j c t}$

where Fee is either the total expense ratio, management fee or administrative fee of fund $i$ that was set up by fund company $j$ in country $c$ and year $t$. FUNDTYPE refers to a set of dummy variables for different fund types. We distinguish between allocation, fixed income, money market and alternative funds. Equity funds are the benchmark. In addition, we include a dummy variable for institutional (INSTITUTIONAL) and guarantee funds (GUARANTEE).

$X$ is a matrix of fund-specific, $Z$ a matrix of company-specific variables and $Y$ a matrix of country controls. The fund-specific variables used are the size of the fund (FUNDSIZE), fund age (FUNDAGE) and the number of countries in which a fund is sold (SALE). Firmspecific controls are size (FIRMSIZE), age of the fund company (FIRMAGE) and the degree of product specialization (SPECIAL). In addition, we test whether foreign fund companies have competitive disadvantages relative to domestic fund companies in issuing funds (FOREIGN). Country variables are included in matrix $Y$ and control for fund-specific regulations such as the requirement of having an independent custodian (CUSTODIAN), the possibility of having umbrella structures (UMBRELLA), the level of taxation of the fund company (TAX) and the time necessary to start a fund (STARTUP). Furthermore, we include a set of variables controlling for the size of the financial sector as well as the overall level of regulation in the financial sector.

For a complete list of variables included in the model see Table 9. $\varepsilon_{i j c t}$ is the error term and $\alpha, \beta_{1}, \beta_{2}, \beta_{3}$ and $\beta_{4}$ are coefficient vectors. To account for the role of Luxembourg and 
Ireland as financial centers, we include dummies for Luxembourg (LU) and Ireland (IE). To remove outliers, we use Cook's (1977) distance criterion. Moreover, since mutual fund fees may not be independent within firms, we use robust standard errors clustered at the level of the fund company. ${ }^{17}$

\section{[insert Table 9 about here]}

The potential determinants of mutual fund fees are based on Khorana et al. (2005, 2009). In addition, we use evidence of Lang (2012), who provides background information on the fund company decision process to choose the most favorable domicile in Europe. Based on a survey among executives of 47 fund companies from Europe, he examines which location factors are relevant to start up a UCITS fund and how European countries compete against each other to attract mutual fund companies. The survey results reveal that continuity in legal stability, the approval process and the availability and qualification of specialized experts in a cluster play the most important role. Cost factors such as registration charges, fund company tax burden and labor costs are, in contrast, generally considered to be less important in the domiciliation decision. According to the experts surveyed, Luxembourg is best in four of the five aforementioned factors, while Ireland ranks second based on three out of five of the most relevant location factors. This suggests that the decision to domicile a fund in Luxembourg and Ireland is not primarily driven by location factors usually assumed to reduce costs, but rather by the quality of the workforce and the approval process which may allow companies to set up more innovative and complex funds in a shorter period of time than in other countries.

The regression analysis proceeds in steps to prevent multicollinearity among the explanatory variables and to test whether our results are robust to the inclusion of different

\footnotetext{
${ }^{17}$ We additionally follow Khorana et al. (2009) and cluster fees at the level of fund types. The results are quantitatively and qualitatively the same. The results can be obtained from the authors upon request. Since we think that clustering standard errors at the firm level is more appropriate than at the level of fund types, we report the results with firm-level clustered standard errors.
} 
sets of control variables. First, we include country dummies as well as a set of fund- and firmspecific variables in the model to find out which fund and firm characteristics determine mutual fund fees. We call this our baseline model. Second, we include several regulatory variables to analyze the impact of fund-specific regulations on mutual fund fees. Third, we use several other country-variables to check whether the results for our fund-specific regulatory variables are driven by some other country characteristics. Finally, we test if our results are sensitive to the sample chosen and analyze whether Luxembourg and Ireland have comparative costs advantages in distributing mutual funds abroad compared to all other countries.

\subsection{Baseline Regression}

In the first step of the regression analysis, we include a set of fund- and firm-specific control variables. To control for unobserved heterogeneity across countries, the model is estimated with country dummy variables. Owing to the importance of Luxembourg (LU) and Ireland (IE) as financial centers, we report the coefficients for these dummies. The coefficients of the remaining country dummies are not reported for the sake of brevity. For a description of the variables used in the regression analysis see Table 9. The results of the baseline model are reported in Table 10 (Model 1).

[insert Table 10 about here]

The results suggest that the fund type matters for mutual fund fees. Consistent with Khorana et al. (2009), we find that the fees of allocation (ALLOCATION), alternative (ALTERNATIVE), fixed income (FIXED INCOME) and money market funds (MONEY MARKET) are significantly lower (at the 1-percent level) than the fees of equity funds, the benchmark. Institutional funds have lower fees as well, as indicated by the significant (at the 1-percent level) and negative coefficient for INSTITUTIONAL. Institutional investors are 
organizations pooling large sums of money and their funds may be cheaper than funds that are not set up for institutional investors. Because of their small investor group they do not require extensive marketing expenses and costs to fulfill requirements of private consumer protection. Furthermore, employees in the treasury units of their organizations often specify the investment strategy and take an active part in investment management which may further reduce costs.

In contrast, guarantee funds (GUARANTEE) report significantly (at the 1-percent level) higher total expense ratios and management fees than funds that do not guarantee the value of the initial investment. This contrasts with Khorana et al. (2009). They argue that guarantee funds should have lower fees, since fund management is easier for guarantee funds as they often mimic an underlying index. Guarantee funds may, however, also have higher fees for the investor. First, the set of derivatives required for their strategy may increase transaction costs. Furthermore, derivative elements may reduce price transparency. This may increase mutual fund companies' possibilities to raise fees. Second, an increasing market demand for a protection of the initial investment may enable management companies to charge higher fees for guarantee funds. This argument will also play an important role in the explanation of the outcome when checking for the start-up time later on. However, the increase in the total expense ratio seems to be entirely driven by higher management fees as we do not find evidence that administrative fees are significantly higher for guarantee funds. Higher management fees, hence, seem to be the dominant factor that makes guarantee funds more expensive.

Funds that are set up under the UCITS directive are more expensive for investors as well, as indicated by the significant coefficient for UCITS. These results hold even though we control for the number of countries in which a fund is sold, which is an important determinant of fees, as we will show later. According to our estimates, investors have to pay, on average, a total-expense ratio which is 7 basis points higher for a UCITS fund than for funds that do not 
comply with the UCITS directive. This may reflect the fact that UCITS funds are subject to stricter requirements which increase the costs of UCITS funds compared to non-UCITS funds. The registration procedure of cross-border funds is often complex and leads to uncertainty. UCITS funds benefit from the simplified notification process. Nevertheless, the requirements on which documents have to be presented still differ from country to country. Because of the complexity, the notification procedure has developed into a de facto registration procedure, which can be very time consuming and significantly increases costs (Lang, 2012). ${ }^{18}$ The results also suggest that UCITS funds have higher fund management costs, as indicated by the positive and significant (at the 1-percent level) coefficient in the regression for management fees. In contrast, we find evidence that fund companies offering UCITS funds may benefit from the cost effects of the economies of scale created by a larger market, as indicated by the negative and significant coefficient in the regression for administrative costs (ADFEE).

Furthermore, we include a dummy variable controlling for the nationality of the fund (FOREIGN). FOREIGN does not identify funds sold outside of their domicile (and that are not offshore funds), but it identifies whether funds are set up by a foreign fund company. Ferreira and Ramos (2009) find that fees tend to be higher in countries where foreign mutual fund companies have a larger market share. FOREIGN allows us to identify whether foreign mutual fund companies have cost disadvantages relative to domestic fund companies in domiciling funds. Foreign funds may be disadvantaged by market entry costs, such as company's start-up costs and specialized recruitment. Our results do not provide strong evidence that foreign mutual fund companies offer funds at higher costs. FOREIGN turns out to be insignificant. This indicates that market integration seems to work in the globalized mutual fund industry and that fund companies do not have cost disadvantages compared to

\footnotetext{
${ }^{18}$ UCITS have also become a global brand enjoying considerable success in Asia, Latin America and the Middle East. The governments and the fund associations of Luxembourg and Ireland, for example, arrange international road shows with government officials to advertise the advantages of their country as domiciles for funds.
} 
domestic companies. Furthermore, even if the first-time registration in a foreign country brings about disproportional set-up costs, these disadvantages may not outweigh benefits in the long run.

Fund characteristics are important determinants of mutual fund fees as well. Consistent with Khorana et al. (2009), we find that funds that are sold in many countries are significantly (at the 1-percent level) more expensive than funds sold in a small number of countries (SALE). SALE is positive and significant for management fees as well, but positive and insignificant for administrative fees. The sale of funds in multiple countries drives up fees as funds need to obtain authorization in every country. In addition, increasing distribution expenses are used to finance activities such as advertising, printing of sale literature for other than current investors and especially for payments to broker-dealers and shareholder servicing agents. Selling a fund in multiple countries requires business negotiations on the sales conditions with a larger number of distributors from different countries. Furthermore, with a growing number of distributors their individual market power to minimize the margins of the fund company could also shrink. This effect may also translate into higher fees for investors. ${ }^{19}$ Since funds that are sold abroad are mainly domiciled in Luxembourg and Ireland, in Section 4 we analyze in greater detail whether these countries have comparative cost advantages in distributing funds across borders.

The size of the mutual fund and the fund company is an important determinant of fund fees as well. ${ }^{20}$ The size of a fund is measured by the logarithm of total fund assets (FUND SIZE), while the size of the fund company is the logarithm of total assets under management

\footnotetext{
${ }^{19}$ A comparison of the component costs of average TERs between cross-border and US funds reveals the importance of distribution costs for European funds. For an actively managed equity fund, for example, the average fractions for investment management and distribution of the total fee in 2009 were 42 percent and 37 percent in Europe, respectively, and 51 percent and 14 percent in the US (Moisson, 2009).

${ }^{20}$ Khorana and Servaes (1999) find that large fund companies and companies that have more experience in opening funds are more likely to open new funds.
} 
(FIRM SIZE). ${ }^{21}$ If economies of scale reduce costs, we would expect larger funds and funds that are set up by larger fund companies to have lower fees. The cumulative experience in larger fund companies should lead to lower costs and fees as well (see e.g. Porter, 1980). This is what we find. In line with Collins and Mack (1997), Latzko (1999), Ang and Lin (2001), Latzko (2003) and Chen et al. (2004), we find that the total expense ratio decrease with the size of the fund as reflected by the negative and significant (at the 1-percent level) coefficient for FUND SIZE.

Larger firms also report significantly (at the 1-percent level) lower management fees as indicated by the negative and significant coefficient for FIRM SIZE, while there is no evidence that they decrease as the size of the fund increases. This is in line with the findings of Gao and Livingston (2008) who find that the decrease in fees for larger funds comes from minor expenses (e.g. custodian, printing, registration, auditing fees), not from a change in management fees. To control for the potential non-linearity of fund size and firm, we additionally include squared terms of fund size and firm size. Since they turn out to be insignificant and since the main results remain unchanged, we do not report the results for the sake of brevity. Furthermore, this result may indicate that funds keep their fee structure in spite of growing assets and that established funds are able to charge higher fees as they attract a great demand because they are seen as a more promising investment. ${ }^{22}$

\footnotetext{
${ }^{21}$ The variable FIRM SIZE faces limitations by the Morningstar Database. In contrast to the Lipper database, which only covers Europe, Morningstar refers to each legal firm by its legal name without providing a reference about its relationship to other firms. For example, if firm 'A' has a subsidiary located in Luxembourg called 'A LU' we cannot trace its relationship back to A, especially since variations in firm names are rarely this simple and consistent. Consequently, the firm size tends to be smaller than the true economic size of a group. In addition, results may be contorted if foreign subsidiaries are consistently smaller than their counterparts at home. Firm size is also limited to fund assets under management and excludes any non-mutual fund assets.

${ }^{22}$ Latzko (2003) provides related explanations. The author utilizes a panel data set containing up to seven annual observations on a cross-section of 398 US equity and fixed income funds and analyzes the relationship between asset size and various published categories of fund expenses. Interestingly all categories indicate scale economies in administration, except the payments for distribution, whereby diseconomies of scale were assessed when assets grow. The greatest sources of economies of scale are indicated in operating activities such as custodian, audit and legal, shareholder report, registration fee and managers expenses, although they comprise a small portion of total costs.
} 
The age of a fund may be a relevant determinant of mutual fund fees as well. Hence, we include FUND AGE. FUND AGE is the logarithm of the number of years since the establishment of a fund. In addition, we control for the age of the fund company (FIRM AGE). FIRM AGE is the logarithm of years since the first fund was set up by the fund company. Both variables capture potential experience effects. Older funds and firms should, for example, have had more time to establish well-practiced operating cycles for the domiciliation of funds, which should reduce fees. However, fees may increase if established operating cycles are outdated and lead to inefficiencies. Older firms may also face higher fixed costs when relocating their fund set-up division. In line with Khorana et al. (2009), our results support neither of these hypotheses. FUND AGE and FIRM AGE turn out to be insignificant.

Fees may not only depend on the size or the age of the mutual fund company but also on the degree of product specialization. For this reason, we include SPECIAL. ${ }^{23}$ A priori, we would expect fees of more specialized fund companies to be lower, as fund specialists may generate efficiency gains from experience effects and specialist knowledge. Our results do not support this hypothesis as SPECIAL turns out to be negative, but insignificant in most regressions. Due to the important role of Luxembourg and Ireland for the global industry, we include a dummy variable for Luxembourg (LU) and Ireland (IE). In most of the models, LU is significant and positive, while IE turns out to be mostly significant, but negative for the total expense ratio and management fees. In contrast, both variables are mostly insignificant for administrative fees.

\footnotetext{
${ }^{23}$ Assume, for example, a fund company only issues equity and money market funds. Based on the size of the individual funds, equity funds account for 60 and money market funds for 40 percent of the funds issued. The value for SPECIAL is then calculated as $60^{2}+40^{2}=5,200$. If the fund company had concentrated on equity funds only, SPECIAL would, in contrast, be $100^{2}=10,000$. If it had not concentrated on any type fund and issued the same proportion of every fund type, SPECIAL would be $20^{2}+20^{2}+20^{2}+20^{2}+20^{2}=2,000$. SPECIAL, hence, ranges between 2,000 and 10,000 with higher values indicating a greater degree of product specialization.
} 
There are several possible explanations for our findings. In the past, both countries had tax and regulatory advantages over other EU nations, which helped to attract many fund companies. However, the advantages of this regulatory arbitrage have reduced over time. In particular, the common European framework of UCITS has achieved harmonization across all countries. In view of the functioning processes and the current available unique infrastructure in the funds industry, relocation would entail high costs and uncertainty. In addition, path dependency and lock-in effects (e.g. Porteous, 1999; Sydow et al., 2009) can postpone or even completely eliminate the possibility of relocation. This may lead to higher costs for funds domiciled in Luxembourg than in other countries.

Likewise, the successful launch of funds with higher fees can be explained by the differing sensitivity of investors with respect to costs. These funds are later primarily domiciled in the two unique financial centers. Lang (2012) has shown that the time required for a fund to be set up is of particular importance to its issuance. As reflected in our study, even strong competition between fund companies will not reduce the high fees charged in the initial stages, since fund fees are usually not adjusted throughout its lifetime (see Otten and Bams 2002, 2011). As a result, countries such as Luxembourg, which allow for the quick setup of funds, are especially popular for setting up funds which cater to new trends and are hence high in demand. This may explain why funds from Luxembourg do not charge significantly lower rates than funds from other countries despite the cluster effects, which are usually argued to give funds from Luxembourg comparative advantages relative to funds domiciled in other countries.

\subsection{Regulatory Variables}

Owing to the globalization of financial markets, fund regulation has become an important determinant of location for mutual funds companies. In the EU, the competition for the best regulatory framework has been intensified by the UCITS directive that has introduced a 
product passport for mutual funds allowing any fund registered in one EU country to be sold in any other EU country without a lengthy authorization process. Since a more favorable regulatory environment should result in lower fees in a competitive market, we expect mutual fund fees to be lower in countries which impose fewer regulations on the domestic mutual fund industry. Indirect costs may arise if regulations increase the time-to-market. Hence, we presume that the regulatory environment directly influences the cost to set up and run a fund.

We include several fund-specific regulatory variables in our model to analyze the impact of mutual fund regulations on fees. Since the regulatory variables are time-invariant, the country dummies are dropped from the model. However, given the importance of Luxembourg and Ireland, the dummies for both countries are left in the model. ${ }^{24}$ The results are reported in Models 2 to 4 of Table 10.

The first regulatory variable included is CUSTODIAN. The custodian has a double mission of safekeeping the investment assets and carrying out a number of oversight functions to ensure that the fund company manages the assets in compliance with the law. The custodian fee is usually a percentage of net assets, so that custodian fees do rise with assets. CUSTODIAN measures whether the custodian bank has to be independent from the fund company or not. Functionally separate depositaries are one of the pillars of the UCITS framework. Since the requirement to have an independent custodian should drive up domiciliation costs, we would expect fees to be higher in countries that require an independent custodian (e.g. Germany and France). This is what we find. CUSTODIAN turns out to be significant (at the 1-percent level) and positive indicating that funds charge higher fees if they are required to have an independent custodian.

The second regulatory variable included measures whether umbrella structures are permitted or not (UMBRELLA). An umbrella structure allows a fund company to offer sub-

\footnotetext{
${ }^{24}$ In addition to standard errors clustered at firm level, we check whether our results change when we cluster standard errors at country level. The results are quantitatively and qualitatively the same and not reported for the sake of brevity.
} 
funds which are traded individually but are organized under one legal entity. Since umbrella structures reduce costs, fees should be lower in countries that allow umbrella structures. The results do not support this hypothesis, however. UMBRELLA turns out to be insignificant for the total expense ratio, management fees and administrative fees. A possible explanation is that UMBRELLA is a country variable that does not distinguish between whether funds use these structures or not.

The third fund-specific regulatory variable is TAX. Unlike Khorana et al. (2009), we do not analyze the impact of investor fund tax rates, because it should be irrelevant owing to pervasive double taxation agreements. Instead, we concentrate on the tax rate charged to the fund company in the country of domiciliation. Since taxes reduce profits, we expect fund companies to increase fees if taxes are higher as companies seek to maintain their profit margin. This suggests a positive relationship between fees and taxes. Our results do not support this hypothesis, however. Overall, we do not find consistent evidence that taxation matters for mutual fund fees. This is consistent with Lang (2012). He finds that the fund company tax burden is generally considered less important in the set-up decision by the fund experts who are responsible for domiciliation.

Finally, we add a variable measuring the time necessary to start a mutual fund (STARTUP). Lang (2012) finds that European fund companies prefer to domicile their funds abroad if the start-up time is shorter than at home. The start-up process is almost always initiated by sales staff. The time needed to fulfill authorities' requirements may decide on the sales pitch. Prima facie, one might expect fees of funds with a longer start-up time to be higher because of the possibly higher operating costs for the fund company. But mutual funds with the same underlying assets should follow the pricing mechanism of homogeneous goods stating that companies levy higher fees if they are on the market earlier than other fund companies. This is what we find. STARTUP is negative and significant (at the 1-percent level) for the total expense-ratio. The effect is almost entirely driven by higher administrative 
costs, as STARTUP turns out to be insignificant for management fees. The result indicates that fees are lower if it takes a long time to set up a fund. The duration of the required start-up time leads to more competition on a growing supply-driven fund market over time and results in lower fees. ${ }^{25}$ Furthermore, funds issued earlier may have competitive advantages relative to funds that are issued later. This may be particularly relevant for funds investing in asset classes that are subject to current trends, such as gold or other commodities. This may give fund companies the possibility to raise fees due to less cost-sensitive investors which may be particularly relevant to funds investing in asset classes that are subject to current trends such as gold or other commodities.

\subsection{Further Controls}

Mutual fund fees may depend on other country-specific characteristics as well. For this reason, we include the logarithm of real GDP per capita (GDPPC) and an index of financial freedom (FINFREE) as additional control variables. The results are reported in Models 5, 6 and 7 of Table 10. GDPPC controls for demand-side factors influencing fees in the fund industry. Khorana et al. (2005 and 2009) argue that the demand for mutual funds should be higher in more developed countries, suggesting a positive relationship between mutual fund fees and GDPPC as fund companies should have more power to raise fees if the demand for mutual funds is high. Our results do not support this hypothesis, as GDPPC turns out to be mostly insignificant. Furthermore, we include an index on financial freedom (FINFREE). FINFREE measures restrictions on banking activities and barriers to market access. Since competition among fund companies should be greater when financial freedom is high, we expect FINFREE and fees to be negatively related. Our results support this hypothesis as FINFREE is negative and partly significant for the total expense ratio and management fees

\footnotetext{
${ }^{25}$ Wahal and Wang (2011) show that funds lower their fees to better compete when they face competition from new funds (as defined by the overlap in quarterly holdings).
} 
and always significant for administrative fees. To control for the structure of the financial system in the country where the fund is domiciled, we further include the ratio of stock market capitalization to GDP (STKMCAP) and the ratio of deposit bank assets to GDP (DBAGDP). STKMTCAP measures the size of a country's stock market, while the ratio of deposit bank assets over GDP (DBAGDP) controls for the size of the banking market. Since competition should be greater among financial institutions in countries with larger stock and banking markets, we expect mutual fund fees to be lower in countries with a more developed financial system. This is what we find. As indicated in Table 11 (Model 6, 9, 10 and 12) both variables turn out to be negative and significant in most regressions. More importantly, our results for the fund- and firm-specific variables as well as for the regulatory variables do not change even if we include additional country control variables.

\section{Sample Selection and Model Extension}

In the previous section, we already performed several robustness checks because we tested whether our results hold if we include country dummies as well as different sets of control variables. In this section, we additionally check whether our results depend on the choice of the sample. We are particularly concerned that our results are driven by the large number of funds domiciled in Luxembourg und Ireland.

Luxembourg and Ireland have developed into international financial centers owing to a favorable regulatory environment. They are used as international hubs, i.e. the funds set up in these countries are predominantly sold in other countries. To check whether this has influenced our results, we drop all funds domiciled in Luxembourg and Ireland from our sample. The results are reported in Table 11 (Models 8 to 9). The exclusion of Luxembourg and Ireland considerably reduces the total number of funds observed. The main results, however, remain unchanged. This suggests that our results are not driven by the large number of funds from Luxembourg und Ireland. 
[insert Table 11 about here]

In the previous regressions, we found that mutual funds fees are significantly more expensive when they are sold in many countries. The descriptive analysis has shown that funds domiciled in Luxembourg and Ireland are sold in many more countries than funds from other countries. This suggests that Luxembourg and Ireland have specialized in distributing funds to several countries worldwide. These specialization advantages may make it cheaper to market a mutual fund from these countries in several foreign countries than, for example, from Finland. To analyze whether it is cheaper to distribute funds worldwide from Luxembourg and Ireland than from other countries, we interact SALE with the dummy variables for Luxembourg (SALE*LU) and Ireland (SALE*IE), respectively. The signs of these coefficients can then be used to assess the existence of specialization advantages in these countries. The results with interaction terms are reported in Table 12 (Model 11 to 12).

They indicate that Luxembourg has significant advantages in distributing funds to foreign countries in terms of the total expense ratio and management fees. The negative coefficient suggests that the costs of distributing funds from Luxembourg are significantly lower than for all other countries. For instance, the results in Model 10 suggest that selling a fund in seven instead of only one country increases the total expense ratio by almost 30 basis points. The total expense ratio of a fund domiciled in Luxembourg that is sold in the same number of countries is 24 basis points lower. This is consistent with the hypothesis that Luxembourg has cost advantages in distributing funds abroad. However, there seems to be no significant effect on administrative fees as indicated by the insignificant coefficient for the interaction term for ADFEE. Ireland does not seem to offer specialized advantages in the distribution of funds abroad.

[insert Table 12 about here] 


\section{Conclusion}

We have analyzed the determinants of mutual fund fees around the world with a particular focus on the fund domicile location. By focusing on the place of domicile, we assume that the process of international financial integration leads to greater competition among fund companies and will allow them to concentrate their activities in specialized hubs. This should lower the costs to set up and run a mutual fund. In the EU, financial integration is considered to be one of the key factors for making Europe more efficient and competitive, contributing to sustainable economic growth (European Commission, 2009). Since formerly separated national fund markets have evolved into supranational markets over the past years, fund companies are now better able to choose the country of domicile for new funds. This process should further intensify as a result of the implementation of the new UCITS IV directive in 2011. When fully implemented, fund companies will be able to set up and manage a UCITS fund in another EU Member State without having to comply with local "substance-criteria" of infrastructure, i.e. the de facto requirement of having a subsidiary in the country in which the fund is domiciled. This leads to further decision opportunities for fund companies to optimize their business models geographically, which should further reduce fund fees. This applies not only to funds issued in the future, but also to existing funds merged from different countries with respect to their location commitments.

We examine the total expense ratio, management fee and, additionally, create a compound ratio of both factors in order to approximate the administrative expenses of a fund company. Our results show considerable variation in mutual fund fees across countries. While cost advantages are usually related to cluster effects of financial centers, we find that investors do not actually pay lower fees for funds based in specialized financial centers such as Luxembourg and Ireland compared to funds from most other countries. Likewise, putting together UCITS-compliant funds usually is more expensive for investors primarily due to greater administrative requirements which drive up costs. 
Furthermore, our results strongly suggest that the length of time required to start a mutual fund is important as well. This may be particularly the case for funds investing in asset classes subject to current market trends. In the early stages of an rising market demand, such funds potentially attract a greater number of cost-insensitive investors, which allows fund companies to achieve higher profit margins. Moreover, as time goes by, strong competition leads to lower fees. Consequently, fund companies are anxious to choose a location with a prompt set-up process, wide registration experiences for abroad distribution, and a close cluster of experts in the whole value chain of a fund, such as Luxembourg. Furthermore, the distribution of funds across borders significantly increases fees as funds need to obtain sales partners and authorization in every country.

These disadvantages on the investor's side are outweighed by significant economies of scale that can be generated if the domiciliation of funds is centralized in financial centers. Financial integration creates economic benefits by encouraging the concentration of fund specialists in clusters, such as Luxembourg and Ireland. These benefits are reflected by significantly lower costs for the cross-border distribution of Luxembourg-based funds compared to funds domiciled in other countries. Our results suggest that the UCITS passport facilitates market access and allows the concentration of funds in financial centers. As a consequence, funds benefit from economies of scale, since the costs for investors decrease as the size of the funds and the fund companies increases. Fund companies that are more specialized in setting up certain types of mutual funds have lower fees as well, indicating efficiency gains from experience effects and specialist knowledge. Several further key findings emerge. We show that funds in countries protecting investors' assets with independent custodians usually charge higher fees. Similarly, guarantee elements drive up the annual costs of funds, whereas institutional investors bear lower costs. Corporate tax considerations, in contrast, do not seem to be the main motive to choose the location to set up mutual funds. Foreign fund companies do not have cost disadvantages compared with 
domestic companies. Overall, the UCITS framework leads to significant cost reductions, lower mutual funds fees and, thus, greater economic welfare. Our results strongly indicate that market integration seems to work in the globalized mutual fund industry. 


\section{References}

ANG, J. and W. LIN (2001): A Fundamental Approach to Estimating Economies of Scale and Scope of Financial Products: The Case of Mutual Funds, Review of Quantitative Finance and Accounting, 16(3), 205-222.

BARBER, B.-M., T. ODEAN, and L. ZHENG (2005): Out of Sight, Out of Mind: The Effects of Expenses on Mutual Fund Flows, Journal of Business, 78(6), 2095-2120.

BÄR, M, A. KEMPF, and S. RUENZI (2011): Is a Team Different from the Sum of Its Parts? Team Management in the Mutual Fund Industry, Review of Finance, 15(2), 359-396.

BAUMOL, W.-J., S.-M. GOLDFELD, L.-A. GORDON, and M.-F. KOEHN (1980): The economics of mutual fund markets: Competition versus regulation, Kluwer Academic, Boston, MA.

BERGSTRESSER, D., J. CHALMERS, and P. TUFANO (2009): Assessing the Costs and Benefits of Brokers in the Mutual Fund Industry, Review of Financial Studies, 22(10), 41294156.

CARHART, M.-M. (1997): On Persistence in Mutual Fund performance, Journal of Finance, 52(1), 57-82.

CHEN, J., H. HONG, M. HUANG, and J. KUBIK (2004): Does fund size erode performance? Liquidity, organizational diseconomies, and active money management, American Economic Review, 94, 1276-1302.

CHEVALIER, J.-A. and G.-D. ELLISON (1999): Are some mutual fund managers better than others? Cross-sectional patterns in behavior and performance, Journal of Finance 54, 875899.

CHORDIA, T. (1996): The Structure of Mutual Fund Charges, Journal of Financial Economics, 41(1), 3-39.

CHRISTOFFERSEN, S. and D.-K. MUSTO (2002): Demand curves and the pricing of money management, Review of Financial Studies, 15, 1499-1524.

COHEN, L., A. FRAZZINI, and C.-J. MALLOY (2008): The Small World of Investing: Board Connections and Mutual Fund Returns, Journal of Political Economy 116(5), 951-979.

COLLINS, S. and P. MACK (1997): The Optimal Amount of Assets under Management in the Mutual Fund Industry.” Financial Analysts Journal, 53, 67-73.

COOK, R. D. (1977): Detection of Influential Observation in Linear Regression, Technometrics, 19(1), 15-18.

COOPER, M., M. HALLING, and M. LEMMON (2011): Fee dispersion and persistence in the mutual fund industry, Working paper, University of Utah.

DERMINE, J. and L.-H. RÖLLER (1992): Economies of scale and scope in French mutual funds, Journal of Financial Intermediation, 2, 83-90. 
EUROPEAN FUND AND ASSET MANAGEMENT ASSOCIATION (EFAMA) (2010): Fact Book 2010, European Fund and Asset Management Association, Brussels.

ELTON, E. J., GRUBER, M. J., and C. R. BLAKE (2003): Incentive Fees and Mutual Funds, Journal of Finance, 58(2), 779-804.

EUROPEAN COMMISSION (2009): European Financial Integration Report, Working paper, European Commission.

FERNANDO, D., L. D. VITTAS (2003): The Global Growth of Mutual Funds, Working paper 3055, World Bank.

FERREIRA M.-A. and S.-B. RAMOS (2009): Mutual Fund Industry Competition and Concentration: International Evidence, Working paper.

GAO, X. and M. LIVINGSTON, (2008): The Components of Mutual Fund Fees, Financial Markets, Institutions and Instruments, 17(3), 197-223.

GIL-BAZO, J. and P. RUIZ-VERDU (2009): The Relation between Price and Performance in the Mutual Fund Industry, Journal of Finance, 64(5), 2153-2183.

Gruber, M.-J. (1996): Another puzzle: The growth in actively managed mutual funds, Journal of Finance, 51(3), 783-810.

HEINEMANN, F. (2002): The Benefits of Creating a Real EU Market for Investment Funds, Working paper, ZEW.

ICI (2010): Investment Company Fact Book, Investment Company Institute, Washington DC.

KHORANA, A. and H. SERVAES (1999): The Determinants of Mutual Fund Starts, Review of Financial Studies, 12(5), 1043-74.

KHORANA, A. and H. SERVAES (2008): On the Future of the Mutual Fund Industry Around the World, in Yasuyuki Fuchita and Robert E. Litan, eds., Pooling Money: The Future of Mutual Funds, Brookings Institution.

KHORANA, A., H. SERVAES, and P. TUFANO (2005): Explaining the Size of the Mutual Fund Industry Around the World, Journal of Financial Economics, 78(1), 145-185.

KHORANA, A., H. SERVAES, and P. TUFANO (2009): Mutual Fund Fees Around the World, Review of Financial Studies, 22(3), 1279-1310.

KRUGMAN, P. (1991): Increasing Returns and Economic Geography, Journal of Political Economy, 99(3), 483-499.

LANG, G. (2012): What is the Wind behind the Sails to Go Abroad? - Empirical Evidence from the Mutual Fund Industry, Working paper (forthcoming), ZEW.

LATZKO, D. (1999): Economies of scale in mutual fund administration, Journal of Financial Research, 22(3), 331-339.

LATZKO, D. (2003): Mutual Fund Expenses, Working paper, Pennsylvania State University. 
MALKIEL, B.-G. (1995): Returns from investing in equity mutual funds 1971-1991, Journal of Finance, 50, 549-572.

MARTIN, R., and SUNLEY, P. (2006): Path dependence and regional economic evolution, Journal of Economic Geography, 6(4), 395-437.

MOISSON, E. (2009): Profiting from Proliferation?, Lipper FMI White paper.

NANDA, V., M. P. NARAYANAN, and V. A. WARTHER (2000): Liquidity, Investment Ability, and Mutual Fund Structure, Journal of Financial Economics, 57(3), 417-443.

OTTEN, R., and D. BAMS (2002): European mutual fund performance, European Financial Management, 8, 75-101.

OTTEN, R., and D. BAMS (2011): Does Industry Size Matter? Revisiting European Mutual Fund Performance, Working paper, Maastricht University.

PORTEOUS, D. (1999): The Development of Financial Centres: Location, Information, Externalities and Path Dependence, in R. Martin ed., Money and the Space Economy, 95-114, Wiley, Chichester.

PORTER, M. (1980): Competitive Strategy, Free Press, New York.

RUENZI, S. (2006): Optimale Gestaltung von Fondsfamilien, Deutscher Universitäts-Verlag, Wiesbaden.

SIGURDSSON, K. (2007): Asymmetric performance fees in European mutual funds, Working paper, London Business School.

SYDOW, J., G. SCHREYÖGG and J. KOCH (2009): Organizational path dependence: Opening the black box, Academy of Management Review, 34(4), 689-709.

VENABLES, A. (1996): Equilibrium Locations of Vertically Linked Industries, International Economic Review, 37(2), 341-359.

WAHAL, S. and Y.-A. WANG (2011): Competition among Mutual Funds, Journal of Financial Economics, 99(1), 40-59.

WILCOX, R.-T. (2003): Bargain hunting or star gazing? How consumers choose mutual Funds, Journal of Business, 76(4), 645-665.

ZHAO, X. (2005): Exit Decisions in the U.S. Mutual Fund Industry, Journal of Business, 78(4), 1365-1401. 


\section{Appendix}

\section{Table 1: Number of fund starts, by year}

Table 1 shows the distribution of mutual funds started by the 1,000 largest fund companies worldwide between 1997 and 2006. The dataset includes all funds not characterized as the oldest share class, which is excluded to account for mistakes caused by duplicity of observations in our data. Furthermore, we drop all observations for which we have no information on fees and fund size.

\begin{tabular}{cccc}
\hline & Obs. & Percent & Cum. \\
\hline 1997 & 985 & 8.39 & 8.39 \\
1998 & 1,076 & 9.17 & 17.56 \\
1999 & 1,109 & 9.45 & 27.01 \\
2000 & 1,355 & 11.55 & 38.56 \\
2001 & 1,080 & 9.2 & 47.76 \\
2002 & 948 & 8.08 & 55.84 \\
2003 & 952 & 8.11 & 63.95 \\
2004 & 1,149 & 9.79 & 73.75 \\
2005 & 1,443 & 12.3 & 86.04 \\
2006 & 1,638 & 13.96 & 100 \\
\hline Total & 11,735 & 100 & \\
\hline
\end{tabular}

\section{Table 2: Number of funds, by fund type}

Table 2 shows the distribution of funds of the 1,000 largest fund companies worldwide according to fund type and the country in which the fund is domiciled. UCITS funds are funds compliant with the UCITS directive. Municipal fixed income funds are excluded as they are mostly driven by tax reasons.

\begin{tabular}{lcccc}
\hline & All Countries & $\begin{array}{c}\text { of which domiciled } \\
\text { in Luxembourg }\end{array}$ & $\begin{array}{c}\text { of which domiciled } \\
\text { in Ireland }\end{array}$ & $\begin{array}{c}\text { of which domiciled in } \\
\text { all other countries }\end{array}$ \\
\hline Allocation & 2,138 & 452 & 13 & 1,673 \\
Alternative & 1,575 & 161 & 2 & 1,412 \\
Equity & 5,497 & 1,543 & 200 & 3,754 \\
Fixed Income & 1,960 & 681 & 96 & 1,183 \\
Money Market & 565 & 97 & 14 & 454 \\
\hline Total & 11,735 & 2,934 & 325 & 8,476 \\
\hline of which non-UCITS & \multicolumn{5}{c}{ of which domiciled } & of which domiciled & of which domiciled in \\
funds & All Countries & in Luxembourg & in Ireland & all other countries \\
\hline Allocation & 1,209 & 98 & 2 & 1,109 \\
Alternative & 1,003 & 32 & 0 & 971 \\
Equity & 2,580 & 68 & 11 & 2,501 \\
Fixed Income & 829 & 54 & 6 & 769 \\
Money Market & 326 & 16 & 2 & 308 \\
\hline Total & 5,947 & 268 & 21 & 5,658 \\
\hline of which UCITS & \multicolumn{5}{c}{ of which domiciled } & of which domiciled & of which domiciled in \\
funds & in Countries & in Luxembourg & in Ireland & all other countries \\
\hline Allocation & 929 & 354 & 11 & 564 \\
Alternative & 572 & 129 & 2 & 441 \\
Equity & 2,917 & 1,475 & 189 & 1,253 \\
Fixed Income & 1,131 & 627 & 90 & 414 \\
Money Market & 239 & 81 & 12 & 146 \\
\hline Total & 5,788 & 2,666 & 304 & 2,818 \\
\hline
\end{tabular}


Table 3: Number of funds, by country

Table 3 shows the geographical distribution of mutual funds of the 1,000 largest fund companies worldwide between 1997 and 2006.

\begin{tabular}{lccc}
\hline Number of Funds & $\begin{array}{c}\text { of which domiciled by } \\
\text { foreign companies }\end{array}$ & $\begin{array}{c}\text { of which domiciled by } \\
\text { domestic companies }\end{array}$ \\
\hline Austria & 542 & 74 & 468 \\
Belgium & 318 & 6 & 312 \\
Switzerland & 193 & 62 & 131 \\
Germany & 529 & 46 & 483 \\
Spain & 1,580 & 171 & 1,409 \\
Finland & 32 & 0 & 32 \\
France & 1,454 & 386 & 1,068 \\
United Kingdom & 690 & 212 & 478 \\
Ireland & 325 & 321 & 4 \\
India & 376 & 149 & 227 \\
Italy & 12 & 0 & 12 \\
Luxembourg & 2,934 & 2511 & 23 \\
Mexico & 59 & 27 & 34 \\
Malaysia & 65 & 0 & 38 \\
Netherlands & 107 & 0 & 107 \\
Norway & 19 & 8 & 19 \\
Portugal & 45 & 2 & 37 \\
Sweden & 12 & 51 & 10 \\
Singapore & 127 & 29 & 76 \\
Thailand & 141 & 78 & 112 \\
Taiwan & 191 & 193 & 113 \\
United States & 1,984 & 4,751 & 1,791 \\
\hline Total & 11,735 & & 6,984 \\
\hline & & & \\
\hline
\end{tabular}




\section{Table 4: Number of countries in which funds are sold, by country}

Table 4 shows the mean, median, standard deviation, maximum and minimum values of the number of countries in which a fund is sold. Funds that are sold in more than one country are distributed across borders, while funds sold in only one country are usually distributed in a single market - the country in which they are domiciled.

\begin{tabular}{lcccccc}
\hline & Obs. & Mean & Median & Std. Dev. & Max. & Min. \\
\hline Austria & 542 & 1.68 & 1.00 & 0.94 & 8.00 & 1.00 \\
Belgium & 318 & 2.80 & 2.00 & 2.75 & 11.00 & 1.00 \\
Switzerland & 193 & 1.09 & 1.00 & 0.32 & 3.00 & 1.00 \\
Germany & 529 & 1.30 & 1.00 & 0.67 & 6.00 & 1.00 \\
Spain & 1,580 & 1.00 & 1.00 & 0.06 & 2.00 & 1.00 \\
Finland & 32 & 2.59 & 2.00 & 0.91 & 5.00 & 2.00 \\
France & 1,454 & 1.25 & 1.00 & 0.97 & 10.00 & 1.00 \\
United Kingdom & 690 & 1.81 & 1.00 & 2.23 & 15.00 & 1.00 \\
Ireland & 325 & 8.70 & 8.00 & 4.82 & 21.00 & 1.00 \\
India & 376 & 1.00 & 1.00 & 0.00 & 1.00 & 1.00 \\
Italy & 12 & 1.00 & 1.00 & 0.00 & 1.00 & 1.00 \\
Luxembourg & 2,934 & 11.97 & 12.00 & 8.16 & 39.00 & 1.00 \\
Mexico & 59 & 1.00 & 1.00 & 0.00 & 1.00 & 1.00 \\
Malaysia & 65 & 1.00 & 1.00 & 0.00 & 1.00 & 1.00 \\
Netherlands & 107 & 1.07 & 1.00 & 0.25 & 2.00 & 1.00 \\
Norway & 19 & 1.26 & 1.00 & 0.56 & 3.00 & 1.00 \\
Portugal & 45 & 1.00 & 1.00 & 0.00 & 1.00 & 1.00 \\
Sweden & 12 & 1.08 & 1.00 & 0.29 & 2.00 & 1.00 \\
Singapore & 127 & 1.32 & 1.00 & 0.68 & 5.00 & 1.00 \\
Thailand & 141 & 1.00 & 1.00 & 0.00 & 1.00 & 1.00 \\
Taiwan & 191 & 1.00 & 1.00 & 0.00 & 1.00 & 1.00 \\
United States & 1,984 & 1.05 & 1.00 & 0.23 & 3.00 & 1.00 \\
\hline Total & 11,735 & 4.15 & 1.00 & 6.33 & 39.00 & 1.00 \\
\hline & & & & & & \\
\hline
\end{tabular}




\section{Table 5: Mutual fund fees, by country}

Table 5 shows weighted and asset-weighted means of mutual fund fees. Fees are weighted by fund size. Mutual fund fees are measured by the total expense ratio (TER), management fees (MGFEE) and administrative fees (ADFEE). Administrative fees are calculated as the difference between the total expense ratio and management fees. All fees are displayed in percent.

\begin{tabular}{|c|c|c|c|c|c|c|}
\hline & \multicolumn{2}{|c|}{ Total Expense Ratio } & \multicolumn{2}{|c|}{ Management Fees } & \multicolumn{2}{|c|}{ Administrative Fees } \\
\hline & Unweighted & Weighted & Unweighted & Weighted & Unweighted & Weighted \\
\hline Austria & 1.72 & 1.36 & 1.09 & 0.94 & 0.63 & 0.42 \\
\hline Belgium & 1.21 & 1.20 & 0.90 & 0.86 & 0.31 & 0.34 \\
\hline Switzerland & 1.06 & 0.59 & 0.89 & 0.52 & 0.17 & 0.07 \\
\hline Germany & 1.40 & 1.08 & 1.00 & 0.87 & 0.39 & 0.21 \\
\hline Spain & 1.22 & 1.14 & 0.95 & 0.87 & 0.27 & 0.27 \\
\hline Finland & 1.82 & 1.92 & 1.65 & 1.78 & 0.17 & 0.14 \\
\hline France & 1.68 & 1.11 & 1.06 & 0.76 & 0.62 & 0.35 \\
\hline United Kingdom & 1.44 & 1.19 & 1.16 & 1.02 & 0.28 & 0.17 \\
\hline Ireland & 1.39 & 1.05 & 1.05 & 0.83 & 0.34 & 0.22 \\
\hline India & 1.64 & 1.09 & 0.78 & 0.56 & 0.85 & 0.53 \\
\hline Italy & 1.55 & 0.62 & 1.25 & 0.49 & 0.31 & 0.13 \\
\hline Luxembourg & 1.64 & 1.45 & 1.20 & 1.10 & 0.44 & 0.35 \\
\hline Mexico & 1.61 & 1.39 & 0.85 & 0.55 & 0.76 & 0.84 \\
\hline Malaysia & 1.48 & 1.20 & 1.29 & 1.11 & 0.18 & 0.09 \\
\hline Netherlands & 1.11 & 0.85 & 0.94 & 0.74 & 0.17 & 0.11 \\
\hline Norway & 1.35 & 1.29 & 1.27 & 1.22 & 0.08 & 0.07 \\
\hline Portugal & 1.42 & 1.18 & 1.17 & 0.92 & 0.25 & 0.27 \\
\hline Sweden & 1.55 & 1.56 & 1.30 & 1.32 & 0.25 & 0.24 \\
\hline Singapore & 1.93 & 1.67 & 1.28 & 1.26 & 0.65 & 0.41 \\
\hline Thailand & 0.97 & 0.86 & 0.75 & 0.67 & 0.21 & 0.19 \\
\hline Taiwan & 1.57 & 1.02 & 1.36 & 0.83 & 0.21 & 0.19 \\
\hline United States & 1.07 & 0.81 & 0.64 & 0.51 & 0.43 & 0.30 \\
\hline Total & 1.43 & 1.08 & 1.00 & 0.78 & 0.43 & 0.30 \\
\hline
\end{tabular}




\section{Table 6: Mutual fund fees, by fund type}

Table 6 shows weighted and asset-weighted means of mutual fund fees for different types of funds. Fees are weighted by fund size. Mutual fund fees are measured by the total expense ratio (TER), management fees (MGFEE) and administrative fees (ADFEE). Administrative fees are calculated as the difference between the total expense ratio and management fees. All fees are displayed in percent.

\section{Total Expense Ratio}

\begin{tabular}{lcccccc}
\hline & Obs. & Mean & Median & Std. Dev. & Max. & Min. \\
\hline Allocation & 2,138 & 1.19 & 1.25 & 0.75 & 6.97 & 0.06 \\
Alternative & 1,575 & 1.37 & 1.35 & 0.55 & 4.32 & 0.02 \\
Equity & 5,497 & 1.34 & 1.34 & 0.67 & 7.17 & 0.05 \\
Fixed Income & 1,960 & 0.91 & 0.90 & 0.49 & 4.39 & 0.05 \\
Money Market & 565 & 0.39 & 0.30 & 0.30 & 2.50 & 0.04 \\
\hline Total & 11,735 & 1.08 & 1.03 & 0.68 & 7.17 & 0.02 \\
\hline
\end{tabular}

\section{Management Fees}

\begin{tabular}{lcccccc}
\hline & Obs. & Mean & Median & Std. Dev. & Max. & Min. \\
\hline Allocation & 2,138 & 0.81 & 0.81 & 0.58 & 2.97 & 0.01 \\
Alternative & 1,575 & 1.01 & 1.00 & 0.45 & 2.46 & 0.01 \\
Equity & 5,497 & 0.99 & 0.90 & 0.53 & 3.00 & 0.01 \\
Fixed Income & 1,960 & 0.66 & 0.64 & 0.36 & 2.25 & 0.02 \\
Money Market & 565 & 0.25 & 0.20 & 0.20 & 1.91 & 0.01 \\
\hline Total & 11,735 & 0.78 & 0.71 & 0.53 & 3.00 & 0.01 \\
\hline
\end{tabular}

Administrative Fees

\begin{tabular}{lcccccc}
\hline & Obs. & Mean & Median & Std. Dev. & Max. & Min. \\
\hline Allocation & 2,138 & 0.39 & 0.24 & 0.47 & 5.97 & 0.01 \\
Alternative & 1,575 & 0.36 & 0.20 & 0.42 & 2.85 & 0.01 \\
Equity & 5,497 & 0.36 & 0.30 & 0.33 & 6.05 & 0.01 \\
Fixed Income & 1,960 & 0.25 & 0.18 & 0.26 & 3.39 & 0.00 \\
Money Market & 565 & 0.14 & 0.09 & 0.19 & 2.21 & 0.00 \\
\hline Total & 11,735 & 0.30 & 0.20 & 0.33 & 6.05 & 0.00 \\
\hline
\end{tabular}




\section{Table 7: Mutual fund fees, by number of countries in which a fund is sold}

Table 7 shows the mean, median, standard deviation, maximum and minimum values of mutual fund fees. Fees are weighted by fund size. Mutual fund fees are measured by the total expense ratio (TER), management fees (MGFEE) and administrative fees (ADFEE). Administrative fees are calculated as the difference between the total expense ratio and management fees. All fees are displayed in percent.

\section{Total Expense Ratio}

\begin{tabular}{lcccccc}
\hline & Obs. & Mean & Median & Std. Dev. & Max. & Min. \\
\hline 1 & 7,545 & 0.91 & 0.88 & 0.59 & 6.60 & 0.02 \\
2 to 3 & 1,473 & 0.96 & 0.81 & 0.69 & 7.17 & 0.07 \\
3 to 5 & 322 & 1.32 & 1.19 & 0.58 & 4.36 & 0.17 \\
5 to 7 & 232 & 1.45 & 1.31 & 1.05 & 6.97 & 0.17 \\
over 7 & 2,163 & 1.50 & 1.58 & 0.64 & 4.79 & 0.16 \\
\hline Total & 11,735 & 1.08 & 1.03 & 0.68 & 7.17 & 0.02 \\
\hline
\end{tabular}

\section{Management Fees}

\begin{tabular}{lcccccc}
\hline & Obs. & Mean & Median & Std. Dev. & Max. & Min. \\
\hline 1 & 7,545 & 0.62 & 0.60 & 0.45 & 3.00 & 0.01 \\
2 to 3 & 1,473 & 0.71 & 0.60 & 0.53 & 3.00 & 0.03 \\
3 to 5 & 322 & 1.09 & 1.00 & 0.51 & 3.00 & 0.09 \\
5 to 7 & 232 & 1.05 & 1.02 & 0.62 & 2.75 & 0.05 \\
over 7 & 2,163 & 1.15 & 1.20 & 0.51 & 2.50 & 0.10 \\
\hline Total & 11,735 & 0.78 & 0.71 & 0.53 & 3.00 & 0.01 \\
\hline
\end{tabular}

Administration Fee

\begin{tabular}{lcccccc}
\hline & Obs. & Mean & Median & Std. Dev. & Max. & Min. \\
\hline 1 & 7,545 & 0.29 & 0.17 & 0.31 & 4.98 & 0.00 \\
2 to 3 & 1,473 & 0.24 & 0.12 & 0.37 & 6.05 & 0.01 \\
3 to 5 & 322 & 0.23 & 0.17 & 0.22 & 3.00 & 0.01 \\
5 to 7 & 232 & 0.41 & 0.16 & 0.74 & 5.97 & 0.01 \\
over 7 & 2,163 & 0.35 & 0.32 & 0.28 & 3.29 & 0.01 \\
\hline Total & 11,735 & 0.30 & 0.20 & 0.33 & 6.05 & 0.00 \\
\hline
\end{tabular}




\section{Table 8: Mutual fund fees, by fund size}

Table 8 shows asset-weighted means of mutual funds of different sizes. Funds are differentiated based on their size in four quartiles. Mutual fund fees are measured by the total expense ratio (TER), management fees (MGFEE) and administrative fees (ADFEE). Administrative fees are calculated as the difference between the total expense ratio and management fees. All fees are displayed in percent.

\section{Total Expense Ratio}

\begin{tabular}{lcccccc}
\hline & Obs. & Mean & Median & Std. Dev. & Max. & Min. \\
\hline 1. Quartile & 2,937 & 1.57 & 1.54 & 0.79 & 7.17 & 0.02 \\
2. Quartile & 2,931 & 1.52 & 1.51 & 0.67 & 6.60 & 0.06 \\
3. Quartile & 2,931 & 1.41 & 1.38 & 0.67 & 5.89 & 0.04 \\
4. Quartile & 2,936 & 1.02 & 0.97 & 0.67 & 6.97 & 0.04 \\
\hline Total & 11,735 & 1.08 & 1.03 & 0.68 & 7.17 & 0.02 \\
\hline
\end{tabular}

\section{Management Fees}

\begin{tabular}{lcccccc}
\hline & Obs. & Mean & Median & Std. Dev. & Max. & Min. \\
\hline 1. Quartile & 2,937 & 1.04 & 1.00 & 0.56 & 3.00 & 0.01 \\
2. Quartile & 2,931 & 1.08 & 1.05 & 0.53 & 3.00 & 0.01 \\
3. Quartile & 2,931 & 1.02 & 1.00 & 0.52 & 3.00 & 0.01 \\
4. Quartile & 2,936 & 0.74 & 0.66 & 0.52 & 2.50 & 0.01 \\
\hline Total & 11,735 & 0.78 & 0.71 & 0.53 & 3.00 & 0.01 \\
\hline
\end{tabular}

\section{Administrative Fees}

\begin{tabular}{lcccccc}
\hline & Obs. & Mean & Median & Std. Dev. & Max. & Min. \\
\hline 1. Quartile & 2,937 & 0.53 & 0.35 & 0.54 & 6.05 & 0.00 \\
2. Quartile & 2,931 & 0.43 & 0.29 & 0.43 & 4.84 & 0.00 \\
3. Quartile & 2,931 & 0.39 & 0.27 & 0.39 & 4.69 & 0.01 \\
4. Quartile & 8,799 & 0.40 & 0.28 & 0.41 & 6.05 & 0.00 \\
\hline Total & 11,735 & 0.30 & 0.20 & 0.33 & 6.05 & 0.00 \\
\hline
\end{tabular}




\section{Table 9: Variables}

Table 9 describes the variables used in the regression analysis.

\begin{tabular}{|c|c|}
\hline Variable & Description \\
\hline ALLOCATION & Dummy variable for allocation funds. Source: Morningstar (2010) \\
\hline ALTERNATIVE & Dummy variable for alternative funds. Source: Morningstar (2010) \\
\hline $\begin{array}{l}\text { FIXED INCOME } \\
\text { MONEY }\end{array}$ & Dummy variable for fixed income funds. Source: Morningstar (2010) \\
\hline MARKET & Dummy variable for money market funds. Source: Morningstar (2010) \\
\hline INSTITUTIONAL & Dummy variable for institutional funds. Source: Morningstar (2010) \\
\hline GUARANTEE & Dummy variable for guarantee funds. Source: Morningstar (2010) \\
\hline UCITS & Dummy variable for UCITS funds. Source: Morningstar (2010) \\
\hline SALE & Number of countries in which a fund is sold. Source: Morningstar (2010) \\
\hline FUND SIZE & Logarithm of the total fund assets, in Euro. Source: Morningstar (2010) \\
\hline FUND AGE & Logarithm of the number of years since the fund was started. Source: Morningstar (2010) \\
\hline FIRM SIZE & $\begin{array}{l}\text { Logarithm of total assets under management, in Euro. Source: Morningstar (2010) } \\
\text { Logarithm of the number of years since the first fund of a fund company was set up. }\end{array}$ \\
\hline FIRM AGE & Source: Morningstar $(2010)$ \\
\hline SPECIAL & $\begin{array}{l}\text { Sum of the squared assets (by fund type) set up by a fund company. Source: Morningstar } \\
(2010)\end{array}$ \\
\hline FOREIGN & $\begin{array}{l}\text { Dummy variable indicating whether a fund was set up in a country other than the home } \\
\text { country of the issuing company. Source: Morningstar (2010) }\end{array}$ \\
\hline IE & Dummy variable for funds domiciled in Ireland. Source: Morningstar (2010) \\
\hline LU & Dummy variable for funds domiciled in Luxembourg. Source: Morningstar (2010) \\
\hline CUSTODIAN & Dummy variable for countries in which a custodian is mandatory. Source: KPMG (2010) \\
\hline UMBRELLA & $\begin{array}{l}\text { Dummy variable for countries in which umbrella structures are allowed. Source: KPMG } \\
\text { (2010) }\end{array}$ \\
\hline & Tax rate charged to the mutual fund company in a country. Source: KPMG (2010), \\
\hline TAX & $\begin{array}{l}\text { Country fund industry associations } \\
\text { Time necessary to start a mutual fund in a country. Source: KPMG (2010), PWC (2010), }\end{array}$ \\
\hline STARTUP & Country fund industry associations \\
\hline GDPPC & Logarithm of the GDP per-capita in a country. Source: WDI (2010) \\
\hline STKMTCAP & Ratio of stock market capitalization to GDP. Source: IMF (2010) \\
\hline DBAGDP & Ratio of deposit-bank assets to GDP. Source: IMF (2010) \\
\hline FINFREE & Index of Financial Freedom. Source: Heritage Foundation (2010) \\
\hline SALE*LU & Interaction term between SALE and LU \\
\hline SALE*IE & Interaction term between SALE and IE \\
\hline
\end{tabular}




\section{Table 10: Regression results}

Table 10 reports the results of regressions with fund-specific regulatory variables. Panel A shows the results for the total expense ratio (TER), Panel B for management fees (MGFEE) and Panel C for administrative fees (ADFEE). Model 1 is the baseline model. Model 2 includes CUSTODIAN and TAX, Model 3 UMBRELLA, and STARTUP. Model 4 includes all fund-specific regulatory variables together. The size of the stock market (STKMTCAP) and the banking system (DBAGDP) are included in Model 5 and real GDP per capita (GDPPC) and the degree of financial freedom (FINFREE) in Model 6. All country variables are included in Model 7. The variables used in the regression analysis are described in Table 9. Regressions are estimated with robust standard errors clustered on the firm level. Country dummies are included in our baseline model (Model 1). ***/**/* indicates significance at the 1-, 5-, and 10-percent level, respectively.

\begin{tabular}{|c|c|c|c|c|c|c|c|}
\hline \multicolumn{8}{|c|}{ Panel A: Total Expense Ratio } \\
\hline ALLOCATION & $\begin{array}{c}-0.216^{* * *} \\
(0.0279)\end{array}$ & $\begin{array}{c}-0.204 * * * \\
(0.0300)\end{array}$ & $\begin{array}{c}-0.210 * * * \\
(0.0293)\end{array}$ & $\begin{array}{c}-0.223 * * * \\
(0.0292)\end{array}$ & $\begin{array}{c}-0.224 * * * \\
(0.0300)\end{array}$ & $\begin{array}{c}-0.219^{* * *} \\
(0.0289)\end{array}$ & $\begin{array}{c}-0.227 * * * \\
(0.0298)\end{array}$ \\
\hline ALTERNATIVE & $\begin{array}{c}-0.907 * * * \\
(0.0954)\end{array}$ & $\begin{array}{c}-0.927 * * * \\
(0.0843)\end{array}$ & $\begin{array}{c}-0.889 * * * \\
(0.0747)\end{array}$ & $\begin{array}{c}-0.985^{* * *} \\
(0.0835)\end{array}$ & $\begin{array}{c}-0.967 * * * \\
(0.0842)\end{array}$ & $\begin{array}{c}-0.959 * * * \\
(0.0828)\end{array}$ & $\begin{array}{c}-0.952 * * * \\
(0.0834)\end{array}$ \\
\hline MONEY MARKET & $\begin{array}{c}-1.102 * * * \\
(0.0356)\end{array}$ & $\begin{array}{c}-1.102 * * * \\
(0.0337)\end{array}$ & $\begin{array}{c}-1.075^{* * *} \\
(0.0379)\end{array}$ & $\begin{array}{c}-1.125^{* * *} \\
(0.0359)\end{array}$ & $\begin{array}{c}-1.113 * * * \\
(0.0364)\end{array}$ & $\begin{array}{c}-1.132 * * * \\
(0.0361)\end{array}$ & $\begin{array}{c}-1.121 * * * \\
(0.0374)\end{array}$ \\
\hline INSTITUTIONAL & $\begin{array}{c}-0.473 * * * \\
(0.0341)\end{array}$ & $\begin{array}{c}-0.484 * * * \\
(0.0345)\end{array}$ & $\begin{array}{c}-0.516^{* * *} \\
(0.0361)\end{array}$ & $\begin{array}{c}-0.490 * * * \\
(0.0359)\end{array}$ & $\begin{array}{c}-0.483 * * * \\
(0.0359)\end{array}$ & $\begin{array}{c}-0.482 * * * \\
(0.0353)\end{array}$ & $\begin{array}{c}-0.478 * * * \\
(0.0354)\end{array}$ \\
\hline SALE & $\begin{array}{c}0.00975^{* * *} * \\
(0.00297)\end{array}$ & $\begin{array}{c}0.0117 * * * \\
(0.00305)\end{array}$ & $\begin{array}{c}0.0130 * * * \\
(0.00286)\end{array}$ & $\begin{array}{c}0.0122 * * * \\
(0.00297)\end{array}$ & $\begin{array}{c}0.00963 * * * \\
(0.00334)\end{array}$ & $\begin{array}{l}0.0108 * * * \\
(0.00292)\end{array}$ & $\begin{array}{c}0.00914 * * * \\
(0.00326)\end{array}$ \\
\hline FUND SIZE & $\begin{array}{c}-0.0420 * * * \\
(0.00652)\end{array}$ & $\begin{array}{c}-0.0472 * * * \\
(0.00718)\end{array}$ & $\begin{array}{c}-0.0548 * * * \\
(0.00681)\end{array}$ & $\begin{array}{c}-0.0499 * * * \\
(0.00670)\end{array}$ & $\begin{array}{c}-0.0474 * * * \\
(0.00664)\end{array}$ & $\begin{array}{c}-0.0464 * * * \\
(0.00653)\end{array}$ & $\begin{array}{c}-0.0458 * * * \\
(0.00648)\end{array}$ \\
\hline FUND AGE & $\begin{array}{c}0.0173 \\
(0.0128)\end{array}$ & $\begin{array}{l}0.0230 * \\
(0.0139)\end{array}$ & $\begin{array}{c}0.0204 \\
(0.0132)\end{array}$ & $\begin{array}{c}0.0181 \\
(0.0132)\end{array}$ & $\begin{array}{c}-0.0351 * * \\
(0.0143)\end{array}$ & $\begin{array}{c}0.000421 \\
(0.0136)\end{array}$ & $\begin{array}{c}-0.0444 * * * \\
(0.0151)\end{array}$ \\
\hline FIRM SIZE & $\begin{array}{c}-0.0396 * * * \\
(0.00750)\end{array}$ & $\begin{array}{c}-0.0358 * * * \\
(0.00751)\end{array}$ & $\begin{array}{c}-0.0454 * * * \\
(0.00800)\end{array}$ & $\begin{array}{c}-0.0415 * * * \\
(0.00771)\end{array}$ & $\begin{array}{c}-0.0404 * * * \\
(0.00761)\end{array}$ & $\begin{array}{c}-0.0414 * * * \\
(0.00769)\end{array}$ & $\begin{array}{c}-0.0409 * * * \\
(0.00760)\end{array}$ \\
\hline FIRM AGE & $\begin{array}{c}0.0157 \\
(0.0320)\end{array}$ & $\begin{array}{l}0.00427 \\
(0.0323)\end{array}$ & $\begin{array}{c}-0.0245 \\
(0.0324)\end{array}$ & $\begin{array}{r}-0.00193 \\
(0.0324)\end{array}$ & $\begin{array}{c}0.0168 \\
(0.0283)\end{array}$ & $\begin{array}{r}0.00490 \\
(0.0331)\end{array}$ & $\begin{array}{c}0.0133 \\
(0.0288)\end{array}$ \\
\hline LUX & $\begin{array}{c}0.468 * * * \\
(0.0831)\end{array}$ & $\begin{array}{c}0.469 * * * \\
(0.108)\end{array}$ & $\begin{array}{c}0.0000490 \\
(0.0665)\end{array}$ & $\begin{array}{c}0.347 * * * \\
(0.103)\end{array}$ & $\begin{array}{c}0.305 * * * \\
(0.0962)\end{array}$ & $\begin{array}{c}0.280^{* * *} \\
(0.102)\end{array}$ & $\begin{array}{c}0.270 * * * \\
(0.0933)\end{array}$ \\
\hline CUSTODIAN & & $\begin{array}{c}0.406 * * * \\
(0.0776)\end{array}$ & & $\begin{array}{l}0.321 * * * \\
(0.0692)\end{array}$ & $\begin{array}{c}0.276^{* * *} \\
(0.0706)\end{array}$ & $\begin{array}{l}0.188 * * \\
(0.0791)\end{array}$ & $\begin{array}{c}0.236 * * * \\
(0.0704)\end{array}$ \\
\hline TAX & & $\begin{array}{c}0.00868 \\
(0.00564)\end{array}$ & & $\begin{array}{c}0.00402 \\
(0.00562)\end{array}$ & $\begin{array}{c}0.0384 \\
(0.0533)\end{array}$ & $\begin{array}{c}0.0676 \\
(0.0709)\end{array}$ & $\begin{array}{l}0.0987^{*} \\
(0.0586)\end{array}$ \\
\hline UMBRELLA & & & $\begin{array}{c}-0.00972 \\
(0.0602)\end{array}$ & $\begin{array}{c}0.0467 \\
(0.0654)\end{array}$ & $\begin{array}{c}-0.0181 * * * \\
(0.00637)\end{array}$ & $\begin{array}{l}-0.00388 \\
(0.00546)\end{array}$ & $\begin{array}{c}-0.0244 * * * \\
(0.00565)\end{array}$ \\
\hline STARTUP & & & $\begin{array}{c}-0.0604 * * * \\
(0.0105)\end{array}$ & $\begin{array}{c}-0.0290 * * * \\
(0.0107)\end{array}$ & $\begin{array}{c}-0.0356 * * * \\
(0.00979)\end{array}$ & $\begin{array}{c}-0.0295 * * * \\
(0.0105)\end{array}$ & $\begin{array}{c}-0.0320^{* * * *} \\
(0.00862)\end{array}$ \\
\hline DBAGDP & & & & & $\begin{array}{c}-0.391 * * * \\
(0.0645)\end{array}$ & & $\begin{array}{c}-0.427 * * * \\
(0.0794)\end{array}$ \\
\hline STMKTCAP & & & & & $\begin{array}{l}-0.0276 \\
(0.0318)\end{array}$ & & $\begin{array}{l}-0.0488 \\
(0.0341)\end{array}$ \\
\hline GDPPC & & & & & & $\begin{array}{r}-0.00445 \\
(0.0193)\end{array}$ & $\begin{array}{l}0.0483 * \\
(0.0247)\end{array}$ \\
\hline FINFREE & & & & & & $\begin{array}{c}-0.00330 * * * \\
(0.00121)\end{array}$ & $\begin{array}{c}-0.00297 * * \\
(0.00121)\end{array}$ \\
\hline Observations & 11,735 & 11,676 & 11,277 & 11,218 & 10,245 & 11,218 & 10,245 \\
\hline
\end{tabular}


Panel B: Management Fees

\begin{tabular}{|c|c|c|c|c|c|c|c|}
\hline & $\begin{array}{c}\text { Model 1 = } \\
\text { Baseline }\end{array}$ & Model 2 & Model 3 & Model 4 & Model 5 & Model 6 & Model 7 \\
\hline ALLOCATION & $\begin{array}{c}-0.207 * * * \\
(0.0216)\end{array}$ & $\begin{array}{c}-0.197 * * * \\
(0.0217)\end{array}$ & $\begin{array}{c}-0.185^{* * *} \\
(0.0228)\end{array}$ & $\begin{array}{c}-0.196^{* * *} \\
(0.0223)\end{array}$ & $\begin{array}{c}-0.193 * * * \\
(0.0232)\end{array}$ & $\begin{array}{c}-0.198 * * * \\
(0.0222)\end{array}$ & $\begin{array}{c}-0.197 * * * \\
(0.0232)\end{array}$ \\
\hline ALTERNATIVE & $\begin{array}{c}-0.736 * * * \\
(0.0785)\end{array}$ & $\begin{array}{c}-0.659 * * * \\
(0.0639)\end{array}$ & $\begin{array}{c}-0.552 * * * \\
(0.0569)\end{array}$ & $\begin{array}{c}-0.673 * * * \\
(0.0663)\end{array}$ & $\begin{array}{c}-0.665^{* * *} \\
(0.0680)\end{array}$ & $\begin{array}{c}-0.664 * * * \\
(0.0665)\end{array}$ & $\begin{array}{c}-0.665 * * * \\
(0.0682)\end{array}$ \\
\hline FIXED INCOME & $\begin{array}{c}-0.504 * * * \\
(0.0180)\end{array}$ & $\begin{array}{c}-0.513 * * * \\
(0.0194)\end{array}$ & $\begin{array}{c}-0.468 * * * \\
(0.0186)\end{array}$ & $\begin{array}{c}-0.485^{* * *} \\
(0.0182)\end{array}$ & $\begin{array}{c}-0.483 * * * \\
(0.0197)\end{array}$ & $\begin{array}{c}-0.480 * * * \\
(0.0178)\end{array}$ & $\begin{array}{c}-0.480 * * * \\
(0.0195)\end{array}$ \\
\hline MONEY MARKET & $\begin{array}{c}-0.818 * * * \\
(0.0278)\end{array}$ & $\begin{array}{c}-0.792 * * * \\
(0.0257)\end{array}$ & $\begin{array}{c}-0.759 * * * \\
(0.0274)\end{array}$ & $\begin{array}{c}-0.796 * * * \\
(0.0268)\end{array}$ & $\begin{array}{c}-0.786^{* * *} \\
(0.0289)\end{array}$ & $\begin{array}{c}-0.798 * * * \\
(0.0270)\end{array}$ & $\begin{array}{c}-0.789 * * * \\
(0.0293)\end{array}$ \\
\hline INSTITUTIONAL & $\begin{array}{c}-0.299 * * * \\
(0.0311)\end{array}$ & $\begin{array}{c}-0.311 * * * \\
(0.0308)\end{array}$ & $\begin{array}{c}-0.336^{* * *} \\
(0.0301)\end{array}$ & $\begin{array}{c}-0.311 * * * \\
(0.0318)\end{array}$ & $\begin{array}{c}-0.311 * * * \\
(0.0316)\end{array}$ & $\begin{array}{c}-0.310 * * * \\
(0.0315)\end{array}$ & $\begin{array}{c}-0.309 * * * \\
(0.0312)\end{array}$ \\
\hline GUARANTEE & $\begin{array}{c}0.418 * * * \\
(0.0857)\end{array}$ & $\begin{array}{c}0.405 * * * \\
(0.0803)\end{array}$ & $\begin{array}{c}0.297 * * * \\
(0.0842)\end{array}$ & $\begin{array}{c}0.401 * * * \\
(0.0826)\end{array}$ & $\begin{array}{c}0.400 * * * \\
(0.0832)\end{array}$ & $\begin{array}{c}0.389 * * * \\
(0.0846)\end{array}$ & $\begin{array}{c}0.395 * * * \\
(0.0852)\end{array}$ \\
\hline UCITSFUND & $\begin{array}{c}0.114 * * * \\
(0.0274)\end{array}$ & $\begin{array}{l}0.148 * * * \\
(0.0248)\end{array}$ & $\begin{array}{l}0.200 * * * \\
(0.0277)\end{array}$ & $\begin{array}{c}0.144 * * * \\
(0.0255)\end{array}$ & $\begin{array}{c}0.145^{* * *} \\
(0.0288)\end{array}$ & $\begin{array}{c}0.143 * * * \\
(0.0267)\end{array}$ & $\begin{array}{c}0.139 * * * \\
(0.0297)\end{array}$ \\
\hline SALE & $\begin{array}{c}0.00852 * * * \\
(0.00292)\end{array}$ & $\begin{array}{c}0.00811^{* * *} \\
(0.00289)\end{array}$ & $\begin{array}{c}0.00971 * * * \\
(0.00295)\end{array}$ & $\begin{array}{c}0.00850 * * * \\
(0.00289)\end{array}$ & $\begin{array}{c}0.00817 * * * \\
(0.00277)\end{array}$ & $\begin{array}{c}0.00850 * * * \\
(0.00294)\end{array}$ & $\begin{array}{c}0.00823 * * * \\
(0.00278)\end{array}$ \\
\hline FUND SIZE & $\begin{array}{l}-0.00658 \\
(0.00540)\end{array}$ & $\begin{array}{l}-0.00858 \\
(0.00545)\end{array}$ & $\begin{array}{c}-0.0165 * * * \\
(0.00580)\end{array}$ & $\begin{array}{c}-0.0108 * * \\
(0.00536)\end{array}$ & $\begin{array}{c}-0.00996^{*} \\
(0.00547)\end{array}$ & $\begin{array}{c}-0.0109 * * \\
(0.00533)\end{array}$ & $\begin{array}{l}-0.0101 * \\
(0.00549)\end{array}$ \\
\hline FUND AGE & $\begin{array}{c}0.00536 \\
(0.00986)\end{array}$ & $\begin{array}{l}0.00962 \\
(0.0102)\end{array}$ & $\begin{array}{l}0.00549 \\
(0.0105)\end{array}$ & $\begin{array}{l}0.00704 \\
(0.0101)\end{array}$ & $\begin{array}{r}-0.00211 \\
(0.0119)\end{array}$ & $\begin{array}{l}0.00556 \\
(0.0110)\end{array}$ & $\begin{array}{l}-0.00679 \\
(0.0122)\end{array}$ \\
\hline FIRM SIZE & $\begin{array}{c}-0.0180 * * * \\
(0.00562)\end{array}$ & $\begin{array}{c}-0.0150 * * * \\
(0.00569)\end{array}$ & $\begin{array}{c}-0.0231 * * * \\
(0.00645)\end{array}$ & $\begin{array}{c}-0.0165^{* * *} \\
(0.00582)\end{array}$ & $\begin{array}{c}-0.0178 * * * \\
(0.00576)\end{array}$ & $\begin{array}{c}-0.0169 * * * \\
(0.00583)\end{array}$ & $\begin{array}{c}-0.0180 * * * \\
(0.00579)\end{array}$ \\
\hline FIRM AGE & $\begin{array}{c}0.0284 \\
(0.0230)\end{array}$ & $\begin{array}{c}0.0263 \\
(0.0225)\end{array}$ & $\begin{array}{c}0.000459 \\
(0.0244)\end{array}$ & $\begin{array}{c}0.0280 \\
(0.0223)\end{array}$ & $\begin{array}{c}0.0246 \\
(0.0205)\end{array}$ & $\begin{array}{c}0.0231 \\
(0.0232)\end{array}$ & $\begin{array}{c}0.0195 \\
(0.0209)\end{array}$ \\
\hline SPECIAL & $\begin{array}{l}-0.00000152 \\
(0.00000713)\end{array}$ & $\begin{array}{c}0.00000333 \\
(0.00000683)\end{array}$ & $\begin{array}{l}-0.00000455 \\
(0.00000775)\end{array}$ & $\begin{array}{c}0.00000151 \\
(0.00000692)\end{array}$ & $\begin{array}{c}0.00000119 \\
(0.00000713)\end{array}$ & $\begin{array}{c}0.00000178 \\
(0.00000701)\end{array}$ & $\begin{array}{c}0.00000136 \\
(0.00000709)\end{array}$ \\
\hline FOREIGN & $\begin{array}{l}-0.0458 \\
(0.0319)\end{array}$ & $\begin{array}{l}-0.0333 \\
(0.0333)\end{array}$ & $\begin{array}{c}-0.0268 \\
(0.0357)\end{array}$ & $\begin{array}{l}-0.0546 \\
(0.0334)\end{array}$ & $\begin{array}{c}-0.0574^{*} \\
(0.0320)\end{array}$ & $\begin{array}{l}-0.0533 \\
(0.0332)\end{array}$ & $\begin{array}{c}-0.0552 * \\
(0.0316)\end{array}$ \\
\hline IE & $\begin{array}{c}0.357 * * * \\
(0.0827)\end{array}$ & $\begin{array}{c}-0.321 * * * \\
(0.0966)\end{array}$ & $\begin{array}{l}-0.161 * * \\
(0.0777)\end{array}$ & $\begin{array}{c}-0.386^{* * *} \\
(0.0981)\end{array}$ & $\begin{array}{c}-0.467 * * * \\
(0.110)\end{array}$ & $\begin{array}{c}-0.403 * * * \\
(0.0969)\end{array}$ & $\begin{array}{c}-0.553 * * * \\
(0.115)\end{array}$ \\
\hline LUX & $\begin{array}{c}0.445^{* * *} \\
(0.0648)\end{array}$ & $\begin{array}{c}0.225^{* * * *} \\
(0.0814)\end{array}$ & $\begin{array}{l}0.00293 \\
(0.0555)\end{array}$ & $\begin{array}{l}0.178 * * \\
(0.0841)\end{array}$ & $\begin{array}{c}0.147 * \\
(0.0800)\end{array}$ & $\begin{array}{l}0.170 * * \\
(0.0842)\end{array}$ & $\begin{array}{c}0.148 * \\
(0.0839)\end{array}$ \\
\hline CUSTODIAN & & $\begin{array}{c}0.214 * * * \\
(0.0523)\end{array}$ & & $\begin{array}{c}0.189 * * * \\
(0.0539)\end{array}$ & $\begin{array}{l}0.150 * * \\
(0.0622)\end{array}$ & $\begin{array}{c}0.191 * * * \\
(0.0633)\end{array}$ & $\begin{array}{l}0.181 * * \\
(0.0745)\end{array}$ \\
\hline TAX & & $\begin{array}{c}-0.0148 * * * \\
(0.00350)\end{array}$ & & $\begin{array}{c}-0.0169 * * * \\
(0.00350)\end{array}$ & $\begin{array}{c}0.0975^{*} \\
(0.0569)\end{array}$ & $\begin{array}{c}0.132 * * * \\
(0.0456)\end{array}$ & $\begin{array}{l}0.138 * * \\
(0.0603)\end{array}$ \\
\hline UMBRELLA & & & $\begin{array}{l}-0.0273 \\
(0.0428)\end{array}$ & $\begin{array}{l}0.110 * * \\
(0.0432)\end{array}$ & $\begin{array}{c}-0.0219 * * * \\
(0.00462)\end{array}$ & $\begin{array}{c}-0.0180 * * * \\
(0.00371)\end{array}$ & $\begin{array}{c}-0.0252 * * * \\
(0.00469)\end{array}$ \\
\hline STARTUP & & & $\begin{array}{c}-0.0450 * * * \\
(0.00850)\end{array}$ & $\begin{array}{l}-0.00902 \\
(0.00748)\end{array}$ & $\begin{array}{l}-0.00922 \\
(0.00805)\end{array}$ & $\begin{array}{l}-0.00619 \\
(0.00732)\end{array}$ & $\begin{array}{l}-0.00612 \\
(0.00784)\end{array}$ \\
\hline DBAGDP & & & & & $\begin{array}{l}-0.0456 \\
(0.0673)\end{array}$ & & $\begin{array}{c}-0.110 \\
(0.0761)\end{array}$ \\
\hline STMKTCAP & & & & & $\begin{array}{l}-0.0126 \\
(0.0348)\end{array}$ & & $\begin{array}{l}-0.0374 \\
(0.0350)\end{array}$ \\
\hline GDPPC & & & & & & $\begin{array}{l}0.0287^{*} \\
(0.0149)\end{array}$ & $\begin{array}{c}0.0424 * * \\
(0.0188)\end{array}$ \\
\hline FINFREE & & & & & & $\begin{array}{c}-0.00129 \\
(0.000860)\end{array}$ & $\begin{array}{l}-0.000804 \\
(0.000924)\end{array}$ \\
\hline Observations & 11,735 & 11,676 & 11,277 & 11,218 & 10,245 & 11,218 & 10,245 \\
\hline
\end{tabular}


Panel C: Administrative Fees

\begin{tabular}{|c|c|c|c|c|c|c|c|}
\hline & $\begin{array}{l}\text { Model 1 = } \\
\text { Baseline }\end{array}$ & Model 2 & Model 3 & Model 4 & Model 5 & Model 6 & Model 7 \\
\hline \multirow[t]{2}{*}{ ALLOCATION } & -0.00891 & -0.00683 & -0.0250 & -0.0265 & -0.0305 & -0.0206 & -0.0296 \\
\hline & $(0.0214)$ & $(0.0229)$ & $(0.0226)$ & $(0.0226)$ & $(0.0243)$ & $(0.0225)$ & $(0.0242)$ \\
\hline \multirow[t]{2}{*}{ ALTERNATIVE } & $-0.171 * * *$ & $-0.268 * * *$ & $-0.337 * * *$ & $-0.312 * * *$ & $-0.302 * * *$ & $-0.295 * * *$ & $-0.286^{* * *}$ \\
\hline & $(0.0391)$ & $(0.0420)$ & $(0.0382)$ & $(0.0418)$ & $(0.0419)$ & $(0.0394)$ & $(0.0402)$ \\
\hline \multirow[t]{2}{*}{ FIXED INCOME } & $-0.188 * * *$ & $-0.189 * * *$ & $-0.192 * * *$ & $-0.186^{* * *}$ & $-0.198 * * *$ & $-0.191 * * *$ & $-0.196 * * *$ \\
\hline & $(0.0172)$ & $(0.0181)$ & $(0.0182)$ & $(0.0180)$ & $(0.0184)$ & $(0.0182)$ & $(0.0182)$ \\
\hline \multirow[t]{2}{*}{ MONEY MARKET } & $-0.285 * * *$ & $-0.310 * * *$ & $-0.316^{* * *}$ & $-0.329 * * *$ & $-0.327 * * *$ & $-0.334 * * *$ & $-0.332 * * *$ \\
\hline & $(0.0268)$ & $(0.0247)$ & $(0.0275)$ & $(0.0261)$ & $(0.0262)$ & $(0.0264)$ & $(0.0269)$ \\
\hline \multirow[t]{2}{*}{ INSTITUTIONAL } & $-0.174 * * *$ & $-0.173 * * *$ & $-0.180 * * *$ & $-0.179 * * *$ & $-0.172 * * *$ & $-0.171 * * *$ & $-0.168 * * *$ \\
\hline & $(0.0177)$ & $(0.0178)$ & $(0.0191)$ & $(0.0177)$ & $(0.0182)$ & $(0.0175)$ & $(0.0181)$ \\
\hline \multirow[t]{2}{*}{ GUARANTEE } & -0.00371 & 0.0414 & $0.0752 *$ & 0.0568 & 0.0517 & 0.0263 & 0.0250 \\
\hline & $(0.0433)$ & $(0.0462)$ & $(0.0400)$ & $(0.0421)$ & $(0.0432)$ & $(0.0418)$ & $(0.0425)$ \\
\hline \multirow[t]{2}{*}{ UCITSFUND } & $-0.0471^{*}$ & $-0.0806 * * *$ & $-0.148 * * *$ & $-0.128 * * *$ & $-0.104 * * *$ & $-0.105^{* * *}$ & $-0.0926 * * *$ \\
\hline & $(0.0259)$ & $(0.0252)$ & $(0.0251)$ & $(0.0249)$ & $(0.0254)$ & $(0.0250)$ & $(0.0254)$ \\
\hline \multirow[t]{2}{*}{ SALE } & 0.00123 & 0.00354 & 0.00326 & 0.00367 & 0.00147 & 0.00230 & 0.000909 \\
\hline & $(0.00285)$ & $(0.00268)$ & $(0.00271)$ & $(0.00268)$ & $(0.00312)$ & $(0.00271)$ & $(0.00308)$ \\
\hline \multirow[t]{2}{*}{ FUND SIZE } & $-0.0355 * * *$ & $-0.0386 * * *$ & $-0.0384 * * *$ & $-0.0391 * * *$ & $-0.0375 * * *$ & $-0.0355 * * *$ & $-0.0357 * * *$ \\
\hline & $(0.00605)$ & $(0.00621)$ & $(0.00617)$ & $(0.00616)$ & $(0.00622)$ & $(0.00625)$ & $(0.00622)$ \\
\hline \multirow[t]{2}{*}{ FUND AGE } & 0.0119 & 0.0134 & 0.0149 & 0.0111 & $-0.0330^{* *}$ & -0.00514 & $-0.0376 * * *$ \\
\hline & $(0.00963)$ & $(0.0101)$ & $(0.0103)$ & $(0.0104)$ & $(0.0128)$ & $(0.0110)$ & $(0.0134)$ \\
\hline \multirow[t]{2}{*}{ FIRM SIZE } & $-0.0216 * * *$ & $-0.0208 * * *$ & $-0.0222 * * *$ & $-0.0250 * * *$ & $-0.0226 * * *$ & $-0.0245 * * *$ & $-0.0229 * * *$ \\
\hline & $(0.00608)$ & $(0.00642)$ & $(0.00652)$ & $(0.00644)$ & $(0.00643)$ & $(0.00634)$ & $(0.00633)$ \\
\hline \multirow[t]{2}{*}{ FIRM AGE } & -0.0127 & -0.0220 & -0.0250 & -0.0300 & -0.00780 & -0.0182 & -0.00622 \\
\hline & $(0.0193)$ & $(0.0206)$ & $(0.0200)$ & $(0.0201)$ & $(0.0183)$ & $(0.0202)$ & $(0.0186)$ \\
\hline \multirow[t]{2}{*}{ SPECIAL } & 0.000000493 & $-0.0000177 * * *$ & $-0.0000165 * * *$ & $-0.0000151 * *$ & -0.00000973 & $-0.0000118^{*}$ & -0.00000802 \\
\hline & $(0.00000635)$ & $(0.00000624)$ & $(0.00000627)$ & $(0.00000626)$ & $(0.00000627)$ & $(0.00000631)$ & $(0.00000631)$ \\
\hline \multirow[t]{2}{*}{ FOREIGN } & 0.00849 & 0.0310 & 0.0397 & 0.0343 & 0.0203 & 0.0288 & 0.0192 \\
\hline & $(0.0313)$ & $(0.0339)$ & $(0.0349)$ & $(0.0334)$ & $(0.0301)$ & $(0.0326)$ & $(0.0294)$ \\
\hline \multirow[t]{2}{*}{ IE } & -0.0752 & $0.374 * * *$ & -0.0912 & $0.270 * * *$ & -0.0214 & $0.216^{* *}$ & -0.0388 \\
\hline & $(0.0662)$ & $(0.0968)$ & $(0.0679)$ & $(0.0941)$ & $(0.115)$ & $(0.0994)$ & $(0.123)$ \\
\hline \multirow[t]{2}{*}{ LUX } & 0.0235 & $0.243 * * *$ & -0.00288 & $0.169 * *$ & $0.158 * *$ & 0.110 & $0.122 *$ \\
\hline & $(0.0594)$ & $(0.0751)$ & $(0.0522)$ & $(0.0691)$ & $(0.0709)$ & $(0.0788)$ & $(0.0714)$ \\
\hline \multirow[t]{2}{*}{ CUSTODIAN } & & $0.192 * * *$ & & $0.132 * * *$ & $0.126^{* *}$ & -0.00247 & 0.0544 \\
\hline & & $(0.0572)$ & & $(0.0502)$ & $(0.0553)$ & $(0.0671)$ & $(0.0613)$ \\
\hline \multirow[t]{2}{*}{ TAX } & & $0.0235 * * *$ & & $0.0209 * * *$ & -0.0590 & -0.0645 & -0.0391 \\
\hline & & $(0.00469)$ & & $(0.00491)$ & $(0.0616)$ & $(0.0615)$ & $(0.0659)$ \\
\hline \multirow[t]{2}{*}{ UMBRELLA } & & & 0.0176 & -0.0636 & 0.00382 & $0.0141 * * *$ & 0.000792 \\
\hline & & & $(0.0496)$ & $(0.0574)$ & $(0.00583)$ & $(0.00544)$ & $(0.00595)$ \\
\hline \multirow[t]{2}{*}{ STARTUP } & & & $-0.0154 * *$ & $-0.0200 * *$ & $-0.0264 * * *$ & $-0.0233 * *$ & $-0.0259 * * *$ \\
\hline & & & $(0.00737)$ & $(0.00932)$ & $(0.00887)$ & $(0.0104)$ & $(0.00893)$ \\
\hline DBAGDP & & & & & $-0.345^{* * *}$ & & $-0.316^{* * *}$ \\
\hline & & & & & $(0.0620)$ & & $(0.0731)$ \\
\hline STMKTCAP & & & & & -0.0150 & & -0.0114 \\
\hline & & & & & $(0.0304)$ & & $(0.0316)$ \\
\hline GDPPC & & & & & & $-0.0332 *$ & 0.00593 \\
\hline & & & & & & $(0.0175)$ & $(0.0208)$ \\
\hline FINFREE & & & & & & $-0.00202 * *$ & $-0.00217^{* *}$ \\
\hline & & & & & & $(0.00101)$ & $(0.000950)$ \\
\hline Observations & 11,735 & 11,676 & 11,277 & 11,218 & 10,245 & 11,218 & 10,245 \\
\hline
\end{tabular}




\section{Table 11: Results for different samples}

Table 11 reports the results of regressions with fund-specific regulatory variables. Panel A shows the results for the total expense ratio (TER), Panel B for management fees (MGFEE) and Panel C for administrative fees (ADFEE). Models 8 and 9 exclude Luxembourg and Ireland. The variables used in the regression analysis are described in Table 9. Regressions are estimated with robust standard errors clustered on the firm level. Country dummies are included in Model $8 . * * * / * * *$ indicates significance at the 1-, 5-, and 10-percent level, respectively.

\begin{tabular}{|c|c|c|}
\hline \multicolumn{3}{|c|}{ Panel A: Total Expense Ratio } \\
\hline & Model 8 & Model 9 \\
\hline \multirow[t]{2}{*}{ ALLOCATION } & $-0.225 * * *$ & $-0.231 * * *$ \\
\hline & $(0.0368)$ & $(0.0366)$ \\
\hline \multirow[t]{2}{*}{ ALTERNATIVE } & $-1.028 * * *$ & $-0.999 * * *$ \\
\hline & $(0.0809)$ & $(0.0817)$ \\
\hline \multirow[t]{2}{*}{ FIXED INCOME } & $-0.696^{* * *}$ & $-0.686 * * *$ \\
\hline & $(0.0383)$ & $(0.0376)$ \\
\hline \multirow[t]{2}{*}{ MONEY MARKET } & $-1.109^{* * *}$ & $-1.100^{* * *}$ \\
\hline & $(0.0434)$ & $(0.0435)$ \\
\hline \multirow[t]{2}{*}{ INSTITUTIONAL } & $-0.436 * * *$ & $-0.417 * * *$ \\
\hline & $(0.0422)$ & $(0.0403)$ \\
\hline \multirow[t]{2}{*}{ GUARANTEE } & $0.525 * * *$ & $0.497 * * *$ \\
\hline & $(0.107)$ & $(0.112)$ \\
\hline \multirow[t]{2}{*}{ UCITSFUND } & -0.0197 & 0.0147 \\
\hline & $(0.0327)$ & $(0.0364)$ \\
\hline \multirow[t]{2}{*}{ SALE } & $0.0478 * *$ & $0.0446^{* *}$ \\
\hline & $(0.0191)$ & $(0.0186)$ \\
\hline \multirow[t]{2}{*}{ FUND SIZE } & $-0.0497 * * *$ & $-0.0448 * * *$ \\
\hline & $(0.00751)$ & $(0.00710)$ \\
\hline \multirow[t]{2}{*}{ FUND AGE } & 0.0201 & $-0.0334 * *$ \\
\hline & $(0.0148)$ & $(0.0156)$ \\
\hline \multirow[t]{2}{*}{ FIRM SIZE } & $-0.0421 * * *$ & $-0.0404 * * *$ \\
\hline & $(0.00894)$ & $(0.00858)$ \\
\hline \multirow[t]{2}{*}{ FIRM AGE } & -0.0145 & 0.0111 \\
\hline & $(0.0336)$ & $(0.0297)$ \\
\hline \multirow[t]{2}{*}{ SPECIAL } & $-0.0000177^{*}$ & -0.00000722 \\
\hline & $(0.00000978)$ & $(0.00000928)$ \\
\hline \multirow[t]{2}{*}{ FOREIGN } & -0.0246 & -0.0401 \\
\hline & $(0.0422)$ & $(0.0399)$ \\
\hline \multirow[t]{2}{*}{ CUSTODIAN } & $0.373 * * *$ & $0.301 * * *$ \\
\hline & $(0.0836)$ & $(0.0820)$ \\
\hline \multirow[t]{2}{*}{ TAX } & 0.0595 & $0.120 * *$ \\
\hline & $(0.0664)$ & $(0.0572)$ \\
\hline \multirow[t]{2}{*}{ UMBRELLA } & 0.00549 & $-0.0259 * * *$ \\
\hline & $(0.00579)$ & $(0.00579)$ \\
\hline \multirow[t]{2}{*}{ STARTUP } & $-0.0235^{* *}$ & $-0.0282 * * *$ \\
\hline & $(0.0111)$ & $(0.00882)$ \\
\hline \multirow[t]{2}{*}{ DBAGDP } & & $-0.491 * * *$ \\
\hline & & $(0.0906)$ \\
\hline \multirow[t]{2}{*}{ STMKTCAP } & & $-0.0644 *$ \\
\hline & & $(0.0372)$ \\
\hline \multirow[t]{2}{*}{ GDPPC } & & $0.0612 * *$ \\
\hline & & $(0.0265)$ \\
\hline \multirow[t]{2}{*}{ FINFREE } & & $-0.00292 * *$ \\
\hline & & $(0.00137)$ \\
\hline Observations & 7,959 & 7,447 \\
\hline
\end{tabular}




\begin{tabular}{|c|c|c|}
\hline & Model 8 & Model 9 \\
\hline \multirow[t]{2}{*}{ ALLOCATION } & $-0.201 * * *$ & $-0.209 * * *$ \\
\hline & $(0.0248)$ & $(0.0257)$ \\
\hline \multirow[t]{2}{*}{ ALTERNATIVE } & $-0.732 * * *$ & $-0.733 * * *$ \\
\hline & $(0.0599)$ & $(0.0648)$ \\
\hline \multirow[t]{2}{*}{ FIXED INCOME } & $-0.476 * * *$ & $-0.467 * * *$ \\
\hline & $(0.0236)$ & $(0.0232)$ \\
\hline \multirow[t]{2}{*}{ MONEY MARKET } & $-0.759 * * *$ & $-0.758 * * *$ \\
\hline & $(0.0284)$ & $(0.0301)$ \\
\hline \multirow[t]{2}{*}{ INSTITUTIONAL } & $-0.240 * * *$ & $-0.229 * * *$ \\
\hline & $(0.0348)$ & $(0.0336)$ \\
\hline \multirow[t]{2}{*}{ GUARANTEE } & $0.475 * * *$ & $0.469 * * *$ \\
\hline & $(0.0762)$ & $(0.0799)$ \\
\hline \multirow[t]{2}{*}{ UCITSFUND } & $0.131 * * *$ & $0.118 * * *$ \\
\hline & $(0.0298)$ & $(0.0342)$ \\
\hline \multirow[t]{2}{*}{ SALE } & $0.0338 * * *$ & $0.0318^{* * *}$ \\
\hline & $(0.0103)$ & $(0.0111)$ \\
\hline \multirow[t]{2}{*}{ FUND SIZE } & $-0.0127 * *$ & $-0.0103 *$ \\
\hline & $(0.00593)$ & $(0.00587)$ \\
\hline \multirow[t]{2}{*}{ FUND AGE } & 0.00815 & -0.00286 \\
\hline & $(0.0120)$ & $(0.0129)$ \\
\hline \multirow[t]{2}{*}{ FIRM SIZE } & $-0.0174 * *$ & $-0.0190 * * *$ \\
\hline & $(0.00693)$ & $(0.00682)$ \\
\hline \multirow[t]{2}{*}{ FIRM AGE } & 0.00348 & -0.00475 \\
\hline & $(0.0216)$ & $(0.0209)$ \\
\hline \multirow[t]{2}{*}{ SPECIAL } & 0.00000787 & 0.00000789 \\
\hline & $(0.00000721)$ & $(0.00000705)$ \\
\hline \multirow[t]{2}{*}{ FOREIGN } & $-0.0653^{*}$ & $-0.0645^{*}$ \\
\hline & $(0.0354)$ & $(0.0334)$ \\
\hline \multirow[t]{2}{*}{ CUSTODIAN } & $0.233 * * *$ & $0.224 * * *$ \\
\hline & $(0.0630)$ & $(0.0861)$ \\
\hline \multirow[t]{2}{*}{ TAX } & $0.105 * *$ & $0.158 * *$ \\
\hline & $(0.0434)$ & $(0.0628)$ \\
\hline \multirow[t]{2}{*}{ UMBRELLA } & $-0.0147 * * *$ & $-0.0240 * * *$ \\
\hline & $(0.00375)$ & $(0.00503)$ \\
\hline \multirow[t]{2}{*}{ STARTUP } & -0.00658 & -0.00318 \\
\hline & $(0.00809)$ & $(0.00837)$ \\
\hline \multirow[t]{2}{*}{ DBAGDP } & & -0.107 \\
\hline & & $(0.0894)$ \\
\hline \multirow[t]{2}{*}{ STMKTCAP } & & $-0.0698 *$ \\
\hline & & $(0.0414)$ \\
\hline \multirow[t]{2}{*}{ GDPPC } & & $0.0511 * *$ \\
\hline & & $(0.0203)$ \\
\hline \multirow[t]{2}{*}{ FINFREE } & & -0.000559 \\
\hline & & $(0.00104)$ \\
\hline Observations & 7,959 & 7,447 \\
\hline
\end{tabular}


Panel C: Administrative Fees

\begin{tabular}{|c|c|c|}
\hline & Model 8 & Model 9 \\
\hline \multirow[t]{2}{*}{ ALLOCATION } & -0.0241 & -0.0218 \\
\hline & $(0.0277)$ & $(0.0276)$ \\
\hline \multirow[t]{2}{*}{ ALTERNATIVE } & $-0.296 * * *$ & $-0.266 * * *$ \\
\hline & $(0.0487)$ & $(0.0468)$ \\
\hline \multirow[t]{2}{*}{ FIXED INCOME } & $-0.220 * * *$ & $-0.219 * * *$ \\
\hline & $(0.0226)$ & $(0.0227)$ \\
\hline \multirow[t]{2}{*}{ MONEY MARKET } & $-0.349 * * *$ & $-0.342 * * *$ \\
\hline & $(0.0293)$ & $(0.0302)$ \\
\hline \multirow[t]{2}{*}{ INSTITUTIONAL } & $-0.196 * * *$ & $-0.188 * * *$ \\
\hline & $(0.0209)$ & $(0.0211)$ \\
\hline \multirow[t]{2}{*}{ GUARANTEE } & 0.0504 & 0.0271 \\
\hline & $(0.0494)$ & $(0.0497)$ \\
\hline \multirow[t]{2}{*}{ UCITSFUND } & $-0.151 * * *$ & $-0.104 * * *$ \\
\hline & $(0.0294)$ & $(0.0306)$ \\
\hline \multirow[t]{2}{*}{ SALE } & 0.0140 & 0.0128 \\
\hline & $(0.0149)$ & $(0.0141)$ \\
\hline \multirow[t]{2}{*}{ FUND SIZE } & $-0.0370 * * *$ & $-0.0345^{* * *}$ \\
\hline & $(0.00666)$ & $(0.00683)$ \\
\hline \multirow[t]{2}{*}{ FUND AGE } & 0.0120 & $-0.0305 * *$ \\
\hline & $(0.0118)$ & $(0.0136)$ \\
\hline \multirow[t]{2}{*}{ FIRM SIZE } & $-0.0247 * * *$ & $-0.0214 * * *$ \\
\hline & $(0.00690)$ & $(0.00676)$ \\
\hline \multirow[t]{2}{*}{ FIRM AGE } & -0.0180 & 0.0159 \\
\hline & $(0.0223)$ & (0.0194) \\
\hline \multirow[t]{2}{*}{ SPECIAL } & $-0.0000256^{* * *}$ & $-0.0000151 * *$ \\
\hline & $(0.00000633)$ & $(0.00000599)$ \\
\hline \multirow[t]{2}{*}{ FOREIGN } & 0.0407 & 0.0244 \\
\hline & $(0.0344)$ & $(0.0305)$ \\
\hline \multirow[t]{2}{*}{ CUSTODIAN } & $0.139 * *$ & 0.0771 \\
\hline & $(0.0593)$ & $(0.0652)$ \\
\hline \multirow[t]{2}{*}{ TAX } & -0.0458 & -0.0379 \\
\hline & $(0.0577)$ & $(0.0688)$ \\
\hline \multirow[t]{2}{*}{ UMBRELLA } & $0.0202 * * *$ & -0.00191 \\
\hline & $(0.00492)$ & $(0.00593)$ \\
\hline \multirow[t]{2}{*}{ STARTUP } & $-0.0169 *$ & $-0.0250 * * *$ \\
\hline & $(0.00931)$ & $(0.00878)$ \\
\hline \multirow[t]{2}{*}{ DBAGDP } & & $-0.384 * * *$ \\
\hline & & $(0.0877)$ \\
\hline \multirow[t]{2}{*}{ STMKTCAP } & & 0.00540 \\
\hline & & $(0.0376)$ \\
\hline \multirow[t]{2}{*}{ GDPPC } & & 0.0101 \\
\hline & & $(0.0222)$ \\
\hline \multirow[t]{2}{*}{ FINFREE } & & $-0.00236 * *$ \\
\hline & & $(0.00103)$ \\
\hline Observations & 7,959 & 7,447 \\
\hline
\end{tabular}




\section{Table 12: Results with interaction terms}

Table 12 reports the regression results for different samples and with interaction terms for SALE. Panel A shows the results for the total expense ratio (TER), Panel $\mathrm{B}$ for management fees (MGFEE) and Panel $\mathrm{C}$ for administrative fees (ADFEE). Models 10, 11 and 12 include an interaction term for SALE. Regressions are estimated with robust standard errors clustered on the firm level. Mutual fund fees are measured by the total expense ratio (TER), management fees (MGFEE) and administrative fees (ADFEE). The variables used in the regression analysis are described in Table $8 . * * * / * * *$ indicates significance at the 1-, 5-, and 10-percent level, respectively.

Panel A: Total Expense Ratio

\begin{tabular}{|c|c|c|c|}
\hline & Model 10 & Model 11 & Model 12 \\
\hline \multirow[t]{2}{*}{ ALLOCATION } & $-0.211 * * *$ & $-0.218^{* * *}$ & $-0.222 * * *$ \\
\hline & $(0.0283)$ & $(0.0297)$ & $(0.0301)$ \\
\hline \multirow[t]{2}{*}{ ALTERNATIVE } & $-0.912 * * *$ & $-0.988 * * *$ & $-0.952 * * *$ \\
\hline & $(0.0948)$ & $(0.0833)$ & $(0.0833)$ \\
\hline \multirow[t]{2}{*}{ FIXED INCOME } & $-0.690 * * *$ & $-0.669 * * *$ & $-0.675 * * *$ \\
\hline & $(0.0263)$ & $(0.0267)$ & $(0.0277)$ \\
\hline \multirow[t]{2}{*}{ MONEY MARKET } & $-1.097 * * *$ & $-1.118 * * *$ & $-1.114 * * *$ \\
\hline & $(0.0353)$ & $(0.0355)$ & $(0.0371)$ \\
\hline \multirow{2}{*}{ INSTITUTIONAL } & $-0.479 * * *$ & $-0.494 * * *$ & $-0.483 * * *$ \\
\hline & $(0.0349)$ & $(0.0367)$ & $(0.0360)$ \\
\hline \multirow[t]{2}{*}{ GUARANTEE } & $0.430 * * *$ & $0.469 * * *$ & $0.428 * * *$ \\
\hline & $(0.115)$ & $(0.108)$ & $(0.113)$ \\
\hline \multirow[t]{2}{*}{ UCITSFUND } & $0.0558^{*}$ & 0.00212 & 0.0350 \\
\hline & $(0.0335)$ & $(0.0284)$ & $(0.0312)$ \\
\hline \multirow[t]{2}{*}{ SALE } & $0.0439 * *$ & $0.0460 * *$ & $0.0451^{* *}$ \\
\hline & $(0.0181)$ & $(0.0192)$ & $(0.0182)$ \\
\hline \multirow[t]{2}{*}{ FUND SIZE } & $-0.0429 * * *$ & $-0.0503 * * *$ & $-0.0466^{* * *}$ \\
\hline & $(0.00639)$ & $(0.00674)$ & $(0.00642)$ \\
\hline \multirow[t]{2}{*}{ FUND AGE } & 0.0165 & 0.0174 & $-0.0460 * * *$ \\
\hline & $(0.0128)$ & $(0.0132)$ & $(0.0151)$ \\
\hline \multirow[t]{2}{*}{ FIRM SIZE } & $-0.0389 * * *$ & $-0.0409 * * *$ & $-0.0403 * * *$ \\
\hline & $(0.00755)$ & $(0.00779)$ & $(0.00768)$ \\
\hline \multirow[t]{2}{*}{ FIRM AGE } & 0.0153 & -0.00267 & 0.0120 \\
\hline & $(0.0311)$ & $(0.0314)$ & $(0.0279)$ \\
\hline \multirow[t]{2}{*}{ SPECIAL } & -0.000000148 & -0.0000129 & -0.00000601 \\
\hline & $(0.00000871)$ & $(0.00000836)$ & $(0.00000864)$ \\
\hline \multirow[t]{2}{*}{ FOREIGN } & -0.0434 & -0.0273 & -0.0452 \\
\hline & $(0.0406)$ & $(0.0420)$ & $(0.0394)$ \\
\hline \multirow[t]{2}{*}{ IE } & 0.216 & -0.130 & $-0.608^{* * *}$ \\
\hline & $(0.138)$ & $(0.171)$ & $(0.174)$ \\
\hline \multirow[t]{2}{*}{ LUX } & $0.538 * * *$ & $0.467 * * *$ & $0.387 * * *$ \\
\hline & $(0.0881)$ & $(0.121)$ & $(0.109)$ \\
\hline \multirow[t]{2}{*}{ CUSTODIAN } & & $0.360 * * *$ & $0.273 * * *$ \\
\hline & & $(0.0792)$ & $(0.0780)$ \\
\hline \multirow[t]{2}{*}{ UMBRELLA } & & 0.0552 & $0.107 *$ \\
\hline & & $(0.0657)$ & $(0.0586)$ \\
\hline \multirow[t]{2}{*}{ TAX } & & 0.00571 & $-0.0232 * * *$ \\
\hline & & $(0.00581)$ & $(0.00574)$ \\
\hline \multirow[t]{2}{*}{ STARTUP } & & $-0.0240 * *$ & $-0.0279 * * *$ \\
\hline & & $(0.0112)$ & $(0.00872)$ \\
\hline GDPPC & & & $0.0505 * *$ \\
\hline & & & $(0.0249)$ \\
\hline FINFREE & & & $-0.00300 * *$ \\
\hline & & & $(0.00121)$ \\
\hline DBAGDP & & & $-0.438 * * *$ \\
\hline & & & $(0.0790)$ \\
\hline STMKTCAP & & & -0.0454 \\
\hline & & & $(0.0344)$ \\
\hline SALE*IE & -0.0207 & -0.0213 & -0.0239 \\
\hline & $(0.0221)$ & $(0.0229)$ & $(0.0222)$ \\
\hline SALE*LU & $-0.0358 * *$ & $-0.0356^{*}$ & $-0.0379 * *$ \\
\hline & $(0.0178)$ & $(0.0187)$ & $(0.0179)$ \\
\hline Observations & 11,735 & 11,218 & 10,245 \\
\hline
\end{tabular}


Panel B: Management Fees

\begin{tabular}{|c|c|c|c|}
\hline & Model 10 & Model 11 & Model 12 \\
\hline \multirow[t]{2}{*}{ ALLOCATION } & $-0.204 * * *$ & $-0.192 * * *$ & $-0.193 * * *$ \\
\hline & $(0.0218)$ & $(0.0224)$ & $(0.0235)$ \\
\hline \multirow[t]{2}{*}{ ALTERNATIVE } & $-0.739 * * *$ & $-0.674 * * *$ & $-0.664 * * *$ \\
\hline & $(0.0781)$ & $(0.0662)$ & $(0.0683)$ \\
\hline \multirow[t]{2}{*}{ FIXED INCOME } & $-0.503 * * *$ & $-0.483 * * *$ & $-0.479 * * *$ \\
\hline & $(0.0178)$ & $(0.0179)$ & $(0.0191)$ \\
\hline \multirow[t]{2}{*}{ MONEY MARKET } & $-0.814 * * *$ & $-0.791 * * *$ & $-0.785 * * *$ \\
\hline & $(0.0278)$ & $(0.0268)$ & $(0.0293)$ \\
\hline \multirow[t]{2}{*}{ INSTITUTIONAL } & $-0.303 * * *$ & $-0.314 * * *$ & $-0.313^{* * *}$ \\
\hline & $(0.0315)$ & $(0.0322)$ & $(0.0316)$ \\
\hline \multirow[t]{2}{*}{ GUARANTEE } & $0.429 * * *$ & $0.409^{* * *}$ & $0.401 * * *$ \\
\hline & $(0.0853)$ & $(0.0823)$ & $(0.0849)$ \\
\hline \multirow[t]{2}{*}{ UCITSFUND } & $0.106 * * *$ & $0.134 * * *$ & $0.131 * * *$ \\
\hline & $(0.0275)$ & $(0.0258)$ & $(0.0295)$ \\
\hline \multirow[t]{2}{*}{ SALE } & $0.0331 * * *$ & $0.0337 * * *$ & $0.0329 * * *$ \\
\hline & $(0.0103)$ & $(0.0106)$ & $(0.0112)$ \\
\hline \multirow[t]{2}{*}{ FUND SIZE } & -0.00720 & $-0.0112 * *$ & $-0.0106^{*}$ \\
\hline & $(0.00530)$ & $(0.00542)$ & $(0.00545)$ \\
\hline \multirow[t]{2}{*}{ FUND AGE } & 0.00490 & 0.00660 & -0.00785 \\
\hline & $(0.00987)$ & $(0.0102)$ & $(0.0123)$ \\
\hline \multirow[t]{2}{*}{ FIRM SIZE } & $-0.0176^{* * *}$ & $-0.0161 * * *$ & $-0.0176^{* * *}$ \\
\hline & $(0.00561)$ & $(0.00581)$ & $(0.00580)$ \\
\hline \multirow[t]{2}{*}{ FIRM AGE } & 0.0278 & 0.0272 & 0.0183 \\
\hline & $(0.0224)$ & $(0.0215)$ & $(0.0203)$ \\
\hline \multirow[t]{2}{*}{ SPECIAL } & -0.00000103 & 0.00000187 & 0.00000168 \\
\hline & $(0.00000718)$ & $(0.00000690)$ & $(0.00000710)$ \\
\hline \multirow[t]{2}{*}{ FOREIGN } & -0.0499 & $-0.0595^{*}$ & $-0.0613^{*}$ \\
\hline & $(0.0322)$ & $(0.0338)$ & $(0.0322)$ \\
\hline \multirow[t]{2}{*}{ IE } & $0.390^{* * *}$ & $-0.315 * *$ & $-0.492 * * *$ \\
\hline & $(0.103)$ & $(0.123)$ & $(0.139)$ \\
\hline \multirow[t]{2}{*}{ LUX } & $0.490 * * *$ & $0.262 * * *$ & $0.223^{* *}$ \\
\hline & $(0.0655)$ & $(0.0913)$ & $(0.0922)$ \\
\hline \multirow[t]{2}{*}{ CUSTODIAN } & & $0.218^{* * *}$ & $0.206^{* *}$ \\
\hline & & $(0.0598)$ & $(0.0804)$ \\
\hline \multirow[t]{2}{*}{ UMBRELLA } & & $0.117 * * *$ & $0.144^{* *}$ \\
\hline & & $(0.0431)$ & $(0.0593)$ \\
\hline \multirow[t]{2}{*}{ TAX } & & $-0.0157 * * *$ & $-0.0244 * * *$ \\
\hline & & $(0.00366)$ & $(0.00489)$ \\
\hline \multirow[t]{2}{*}{ STARTUP } & & -0.00528 & -0.00329 \\
\hline & & $(0.00806)$ & $(0.00802)$ \\
\hline GDPPC & & & $0.0441^{* *}$ \\
\hline & & & $(0.0190)$ \\
\hline FINFREE & & & -0.000821 \\
\hline & & & $(0.000940)$ \\
\hline DBAGDP & & & -0.119 \\
\hline & & & $(0.0759)$ \\
\hline STMKTCAP & & & -0.0350 \\
\hline & & & $(0.0352)$ \\
\hline SALE*IE & $-0.0243^{*}$ & $-0.0252 *$ & $-0.0248^{*}$ \\
\hline & $(0.0132)$ & $(0.0136)$ & $(0.0141)$ \\
\hline SALE*LU & $-0.0254 * * *$ & $-0.0260 * *$ & $-0.0255^{* *}$ \\
\hline & $(0.00979)$ & $(0.0101)$ & $(0.0109)$ \\
\hline Observations & 11,735 & 11,218 & 10,245 \\
\hline
\end{tabular}


Panel C: Administrative Fees

\begin{tabular}{|c|c|c|c|}
\hline & Model 10 & Model 11 & Model 12 \\
\hline \multirow[t]{2}{*}{ ALLOCATION } & -0.00786 & -0.0255 & -0.0285 \\
\hline & $(0.0219)$ & $(0.0232)$ & $(0.0245)$ \\
\hline \multirow[t]{2}{*}{ ALTERNATIVE } & $-0.173 * * *$ & $-0.314 * * *$ & $-0.287 * * *$ \\
\hline & $(0.0390)$ & $(0.0418)$ & $(0.0401)$ \\
\hline \multirow[t]{2}{*}{ FIXED INCOME } & $-0.187 * * *$ & $-0.186^{* * *}$ & $-0.196^{* * *}$ \\
\hline & $(0.0173)$ & $(0.0179)$ & $(0.0182)$ \\
\hline \multirow[t]{2}{*}{ MONEY MARKET } & $-0.283 * * *$ & $-0.326^{* * *}$ & $-0.330 * * *$ \\
\hline & $(0.0265)$ & $(0.0257)$ & $(0.0265)$ \\
\hline \multirow[t]{2}{*}{ INSTITUTIONAL } & $-0.176^{* * *}$ & $-0.180^{* * *}$ & $-0.170 * * *$ \\
\hline & $(0.0182)$ & $(0.0182)$ & $(0.0185)$ \\
\hline \multirow[t]{2}{*}{ GUARANTEE } & 0.000755 & 0.0598 & 0.0276 \\
\hline & $(0.0429)$ & $(0.0424)$ & $(0.0424)$ \\
\hline \multirow[t]{2}{*}{ UCITSFUND } & $-0.0505^{*}$ & $-0.132 * * *$ & $-0.0965 * * *$ \\
\hline & $(0.0262)$ & $(0.0261)$ & $(0.0265)$ \\
\hline \multirow[t]{2}{*}{ SALE } & 0.0108 & 0.0124 & 0.0123 \\
\hline & $(0.0141)$ & $(0.0146)$ & $(0.0137)$ \\
\hline \multirow[t]{2}{*}{ FUND SIZE } & $-0.0357 * * *$ & $-0.0392 * * *$ & $-0.0360 * * *$ \\
\hline & $(0.00600)$ & $(0.00612)$ & $(0.00618)$ \\
\hline \multirow[t]{2}{*}{ FUND AGE } & 0.0116 & 0.0108 & $-0.0382 * * *$ \\
\hline & $(0.00965)$ & $(0.0104)$ & $(0.0135)$ \\
\hline \multirow[t]{2}{*}{ FIRM SIZE } & $-0.0213^{* * *}$ & $-0.0248 * * *$ & $-0.0227 * * *$ \\
\hline & $(0.00610)$ & $(0.00646)$ & $(0.00635)$ \\
\hline \multirow[t]{2}{*}{ FIRM AGE } & -0.0125 & -0.0299 & -0.00635 \\
\hline & $(0.0192)$ & $(0.0200)$ & $(0.0186)$ \\
\hline \multirow[t]{2}{*}{ SPECIAL } & 0.000000882 & $-0.0000148 * *$ & -0.00000769 \\
\hline & $(0.00000631)$ & $(0.00000625)$ & $(0.00000627)$ \\
\hline \multirow[t]{2}{*}{ FOREIGN } & 0.00658 & 0.0323 & 0.0161 \\
\hline & $(0.0315)$ & $(0.0338)$ & $(0.0299)$ \\
\hline \multirow[t]{2}{*}{ IE } & $-0.175^{*}$ & 0.184 & -0.116 \\
\hline & $(0.0898)$ & $(0.126)$ & $(0.140)$ \\
\hline \multirow[t]{2}{*}{ LUX } & 0.0485 & $0.205^{* *}$ & $0.164^{*}$ \\
\hline & $(0.0683)$ & $(0.0930)$ & $(0.0907)$ \\
\hline \multirow[t]{2}{*}{ CUSTODIAN } & & $0.142 * *$ & 0.0661 \\
\hline & & $(0.0571)$ & $(0.0660)$ \\
\hline \multirow[t]{2}{*}{ UMBRELLA } & & -0.0616 & -0.0366 \\
\hline & & $(0.0580)$ & $(0.0665)$ \\
\hline \multirow[t]{2}{*}{ TAX } & & $0.0214^{* * *}$ & 0.00120 \\
\hline & & $(0.00506)$ & $(0.00594)$ \\
\hline \multirow[t]{2}{*}{ STARTUP } & & $-0.0187^{* *}$ & $-0.0246^{* * *}$ \\
\hline & & $(0.00943)$ & $(0.00896)$ \\
\hline GDPPC & & & 0.00645 \\
\hline & & & $(0.0210)$ \\
\hline FINFREE & & & $-0.00218^{* *}$ \\
\hline & & & $(0.000944)$ \\
\hline DBAGDP & & & $-0.319 * * *$ \\
\hline & & & $(0.0742)$ \\
\hline STMKTCAP & & & -0.0104 \\
\hline & & & $(0.0318)$ \\
\hline SALE*IE & 0.00358 & 0.00398 & 0.000861 \\
\hline & $(0.0168)$ & $(0.0175)$ & $(0.0165)$ \\
\hline SALE*LU & -0.0104 & -0.00955 & -0.0124 \\
\hline & $(0.0144)$ & $(0.0146)$ & $(0.0138)$ \\
\hline Observations & 11,735 & 11,218 & 10,245 \\
\hline
\end{tabular}

